تأثير برنامج تدريبي لتنمية تحمل القوة المميزة بالسرعة علي بعض المتغيرات الفسيولوجية ومستوى أداء مهارة رمية الزراع من فوق الظهر للمصارعين

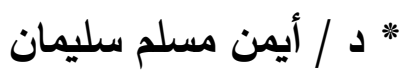

المقدمة ومشكلة البحث:

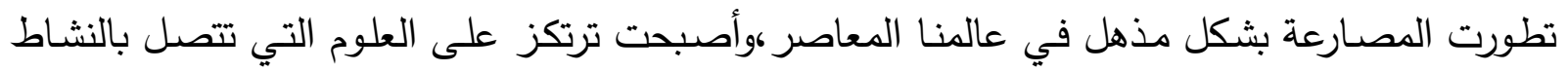

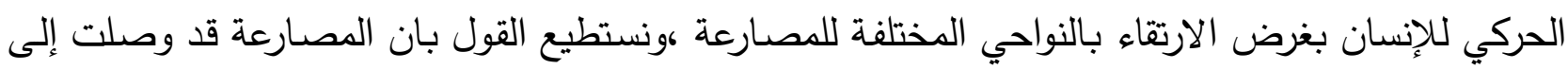

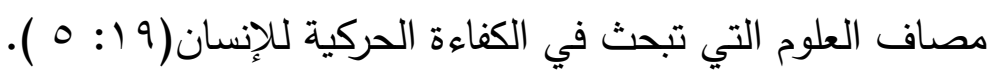

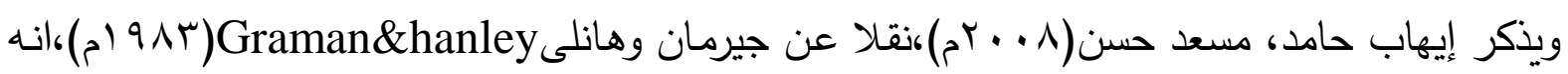
من الضروري أن يتمتع لاعب المصارعة بقدر عالي من اللياقة البدنية حيث يتطلب هذا النشاط بذل جهان وناني كبير

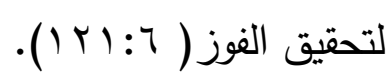
ونظراً للتعديلات التي أقرها الاتحاد الدولي للمصارعة والخاصة بزمن المباراة في نوفمبر ( rا • بم ) حيث

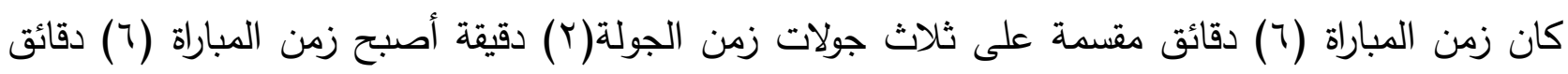

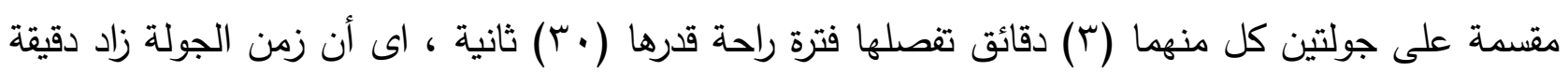

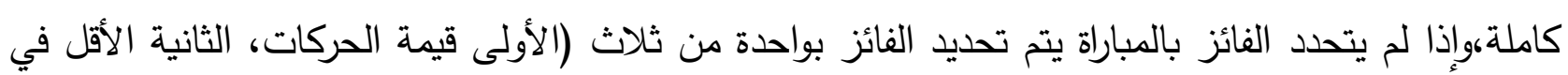

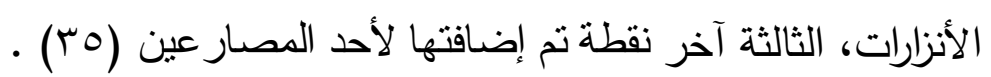
فقد قام الباحث باستطلاع رأى الخبراء، ملحق( r) لتحديد أهم عناصر اللياقة البدنية التي يرتكز عليها

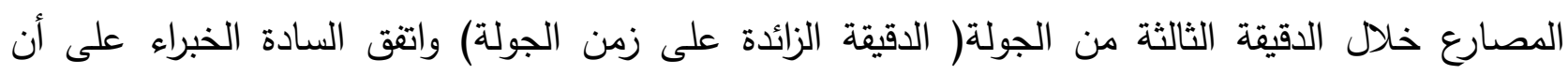

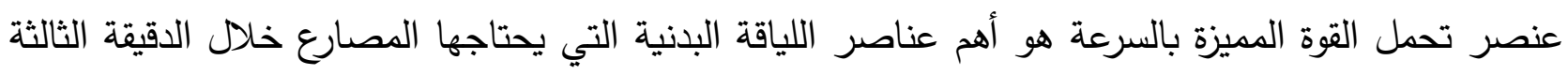

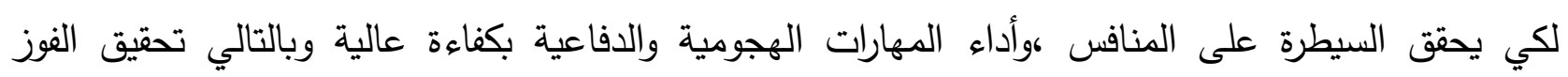
بالمباراة.

ويذكر بسطويسى أحمد (999 (م) أن تحمل القوة المميزة بالسرعة يعتبر عنصر مركب من التحمل والقوة

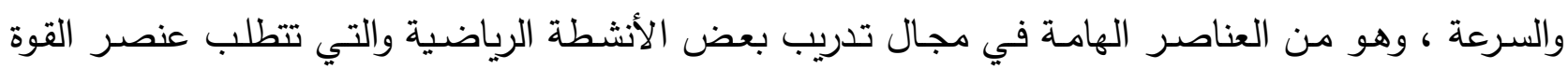

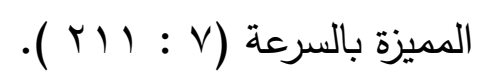

ويضيف مـارتن ومارجريتا Martine \& Margreita (999 (1) أن المصارعة مـ أكثر الأنثطة

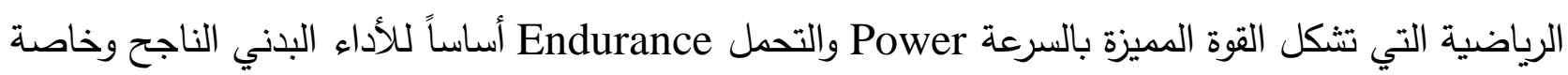

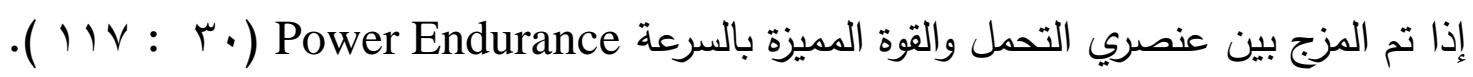

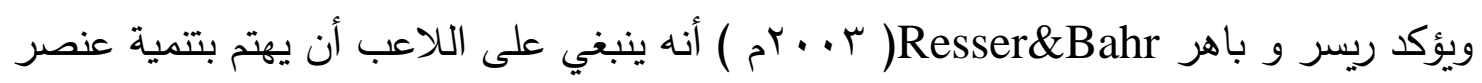
تحمل القوة المميزة بالسرعة جيداً وذلك لأن اللاعبين يشعرون بالتعب في المراحل الأخيرة من المباريات

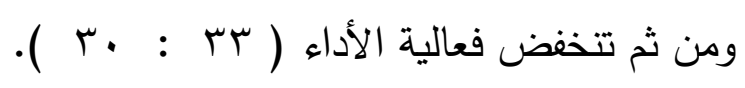

ويضيف باير وجير هارت Bayer\&Gerhart (999 (م) إن امتلاك اللاعب لعنصر تحمل القوة

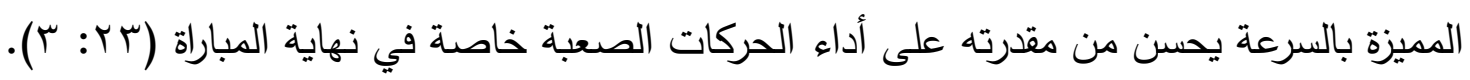


ويذكر ألن بوراس Alan Boraas ( r . . r م) بأن المبدأ الأساسي الخاص بتدريب تحمل القوة المميزة بالسرعة Power Endurance هو تكيف الرياضي للمنافسة لإنتاج الطاقة الهوائية واللاهوائية ، فتدريب تحمل القوة المميزة بالسرعة يرتكز على توصيل الأوكسجين( التنفس،كفاءة القلب )

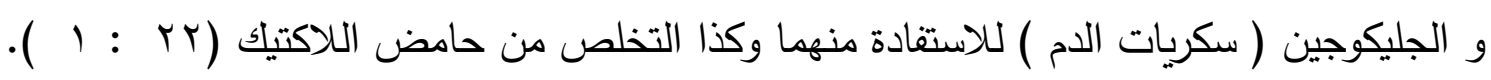

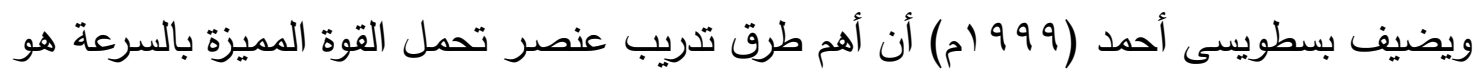

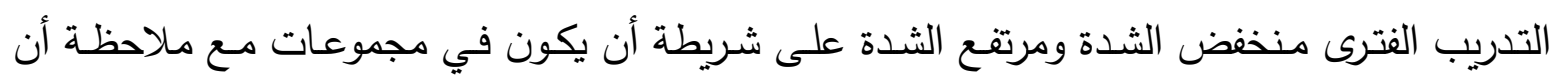

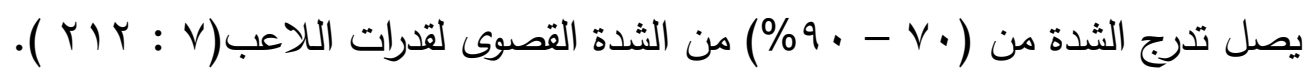

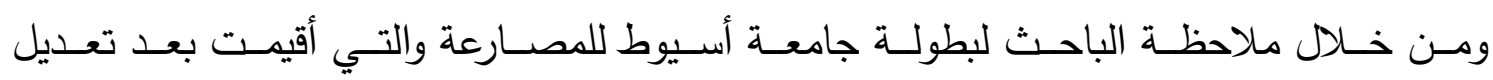
القانون(جولتين كل جولة ب دقائق)،لاحظ ظهور الإجهاد الشديد على اللاعبين ،وعدم قدرة اللاعبين

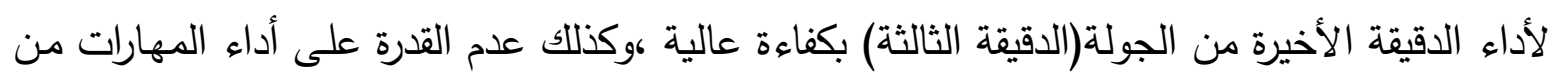

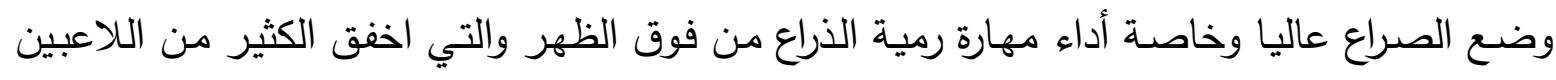

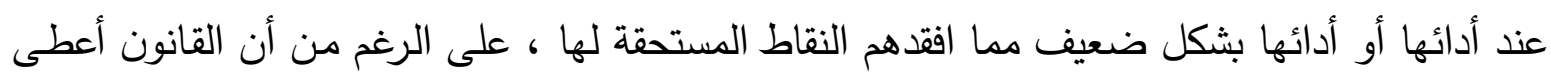

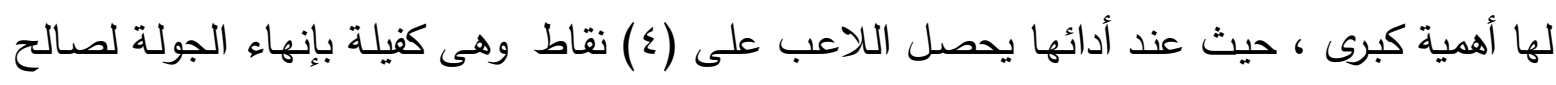

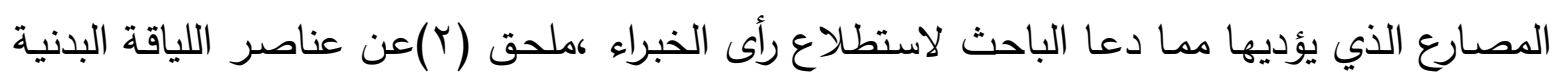

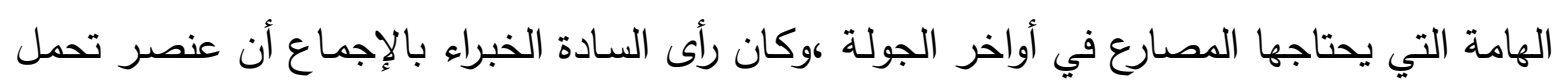

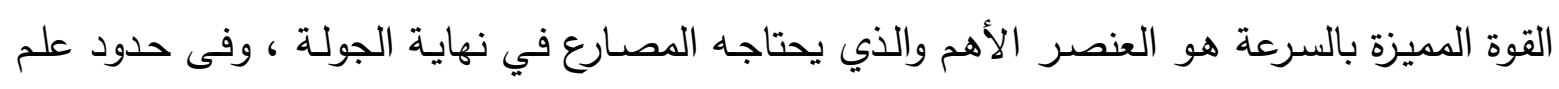

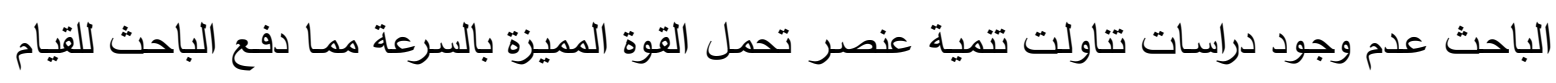

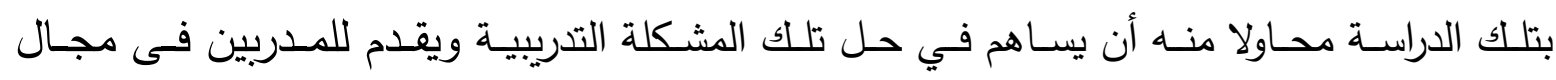
المصـارعة الحلول التدريبية المناسبة والمبنية على اسس علمية بمايحقق الفائدة ويتناسب مـع تعديلات قانون اللعبة . هدف البحث :. معرفة تأثير البرنامج التدريبي المقترح على:1 - تتمية تحمل القوة المميزة بالسرعة للمصارعين.

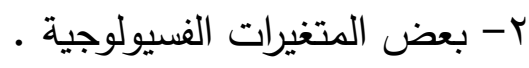
r- مستوى أداء مهارة رمية الزراع من فوق الظهر للمصارعية فين

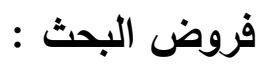

1- توجد فروق دالة إحصائيا بين متوسطات القياسات القبلية والبعدية للمجموعة التجريبية في بعض

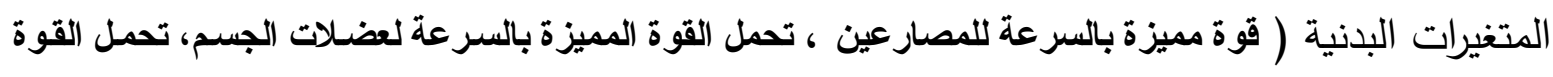

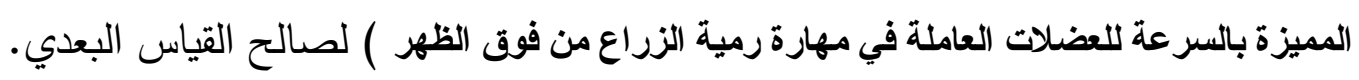




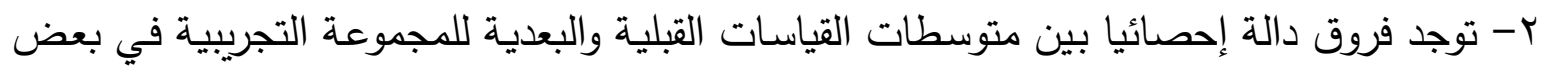

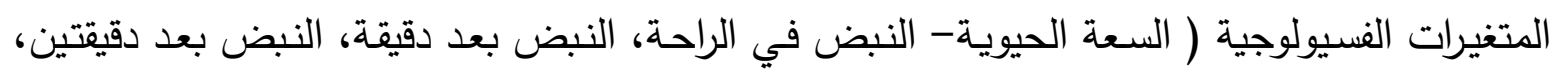

$$
\text { النبض بعد ثلاث دقائق) لصالح القياس البعدي. }
$$

ץ- توجد فروق دالة إحصائيا بين متوسطات القياسات القبلية والبعدية للمجموعة التجريبية في مستوى لدئي أداء مهارة رمية الزراع من فوق الظهر للمصارعين لصالح القياس البعدي.

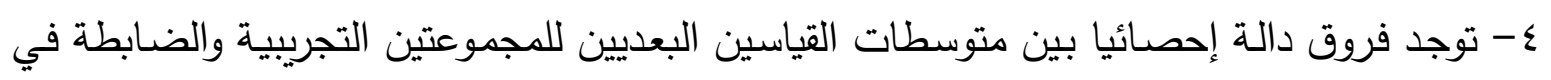

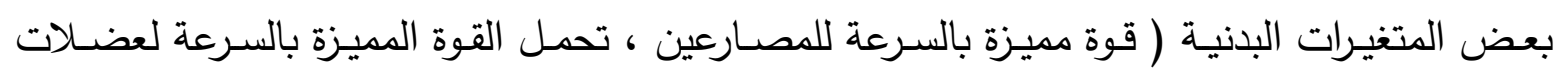

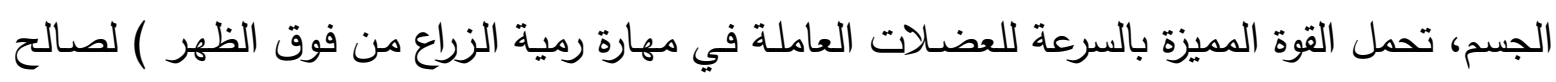
المجموعة التجريبية. ه- توجد فروق دالة إحصائيا بين متوسطات القياسين البعديين للمجموعتين التجريبية والضسابطة في

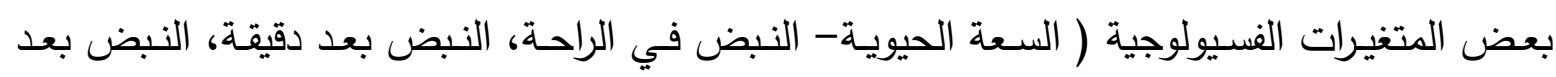
دقيقتين، النبض بعد ثلاث دقائق) لصالح المجموعة التجريبية.

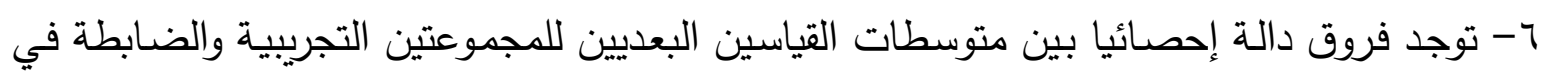
مستوى أداء مهارة رمية الزراع من فوق الظهر للمصارعين لصالح المجموعة التجريبية. المصطلحات المستخدمة:

1- تحمل القوة المميزة بالسرعة للمصارعين:Explosive Strength Endurance For Wrestlers:

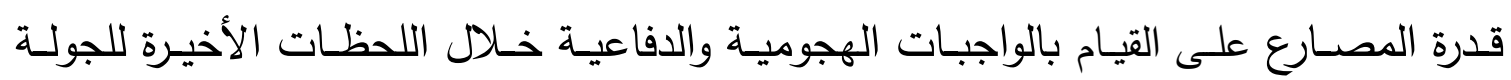

$$
\text { بأقصى قوة وسرعة لأطول فترة ممكنة ( تعريف إجرائي). }
$$

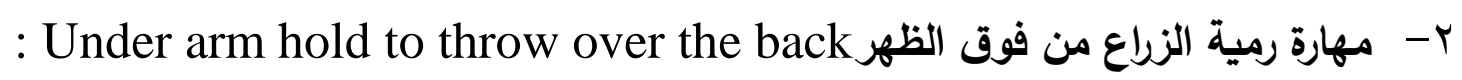
مهارة من وضع الصراع عاليا يقوم فيها المصارع المهاجم بالسيطرة على زراع المصارع السلبي

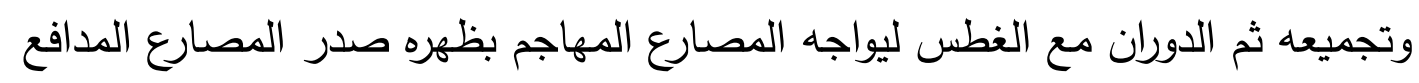
ورميه على البساط بسحب الزراع المسوك مع فرد الركبتين المنثيتين( تعريف إجرائي ).

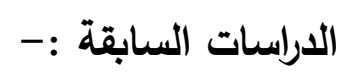

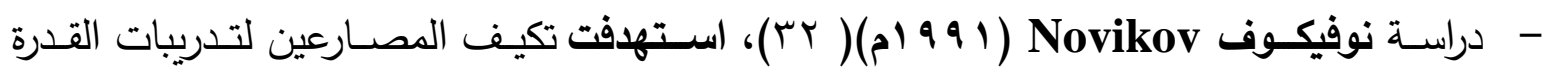

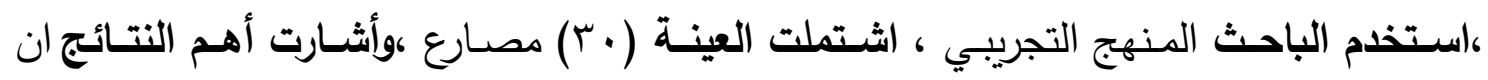

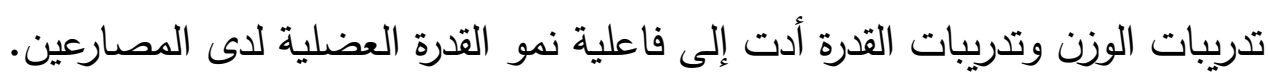

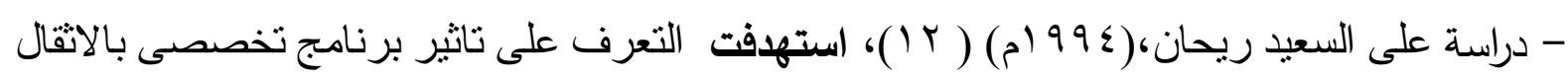

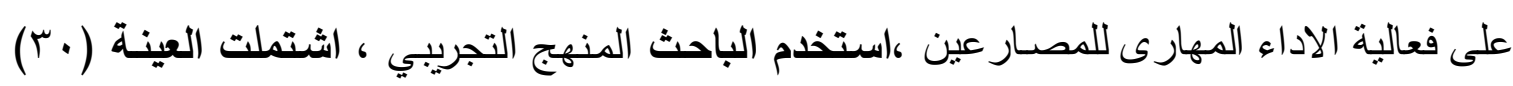

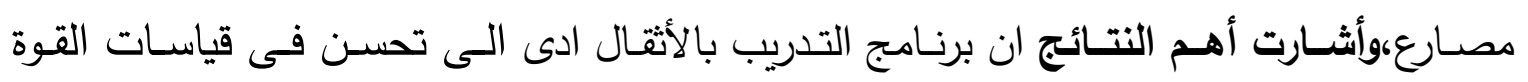
العضلية وكذا فعالية الأداء المهارى لصالح المجموعة التجريبية. 
- دراسة صلاح عسران(997 (19) ( • 1)، استهدفتالتعرف على تاثير استخدام ماكينة الاثقال - الوسائد

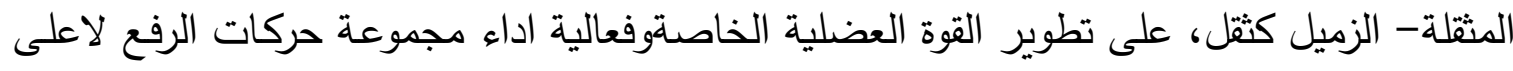

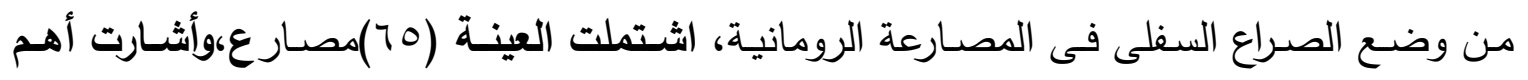

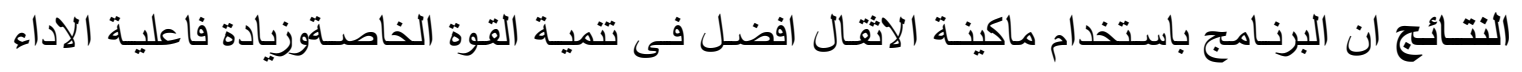

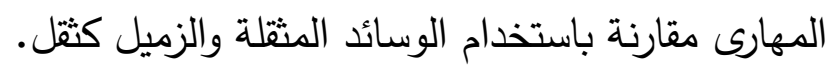

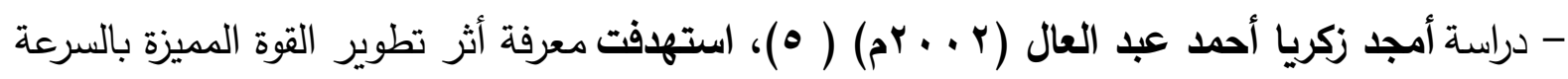
على مستوى أداء مهارة حمل رجل المطافى وبعض المتغيرات الفسيولوجية للمصدارعين، استخدام

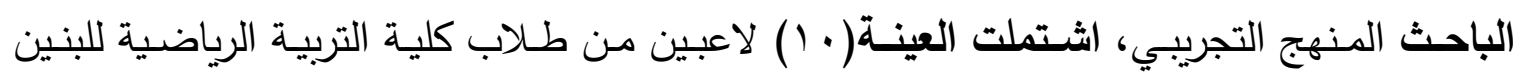

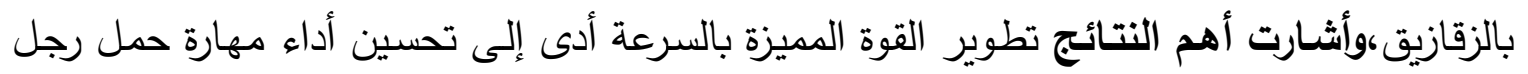
المطافى للمصارعين.

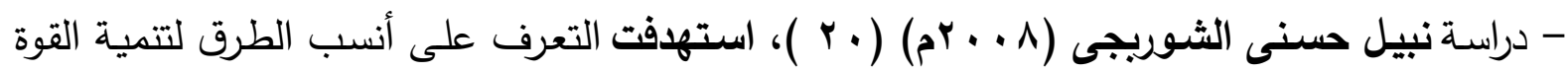

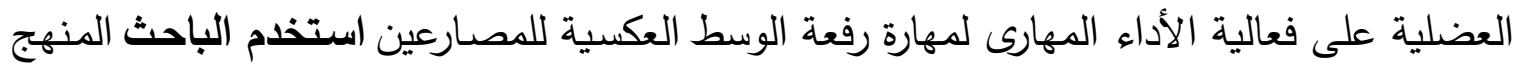

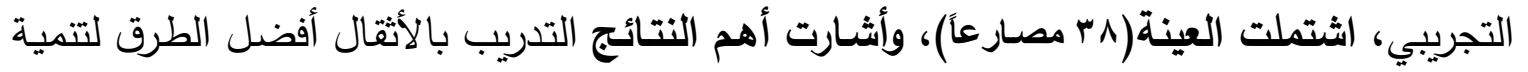
القوة العضلية للمصارعين.

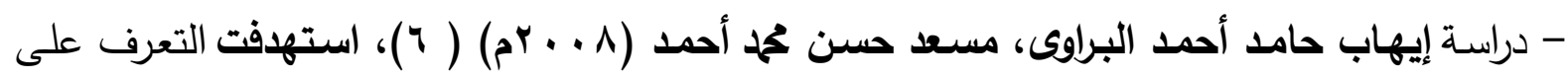

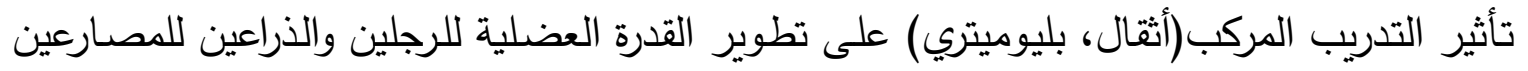

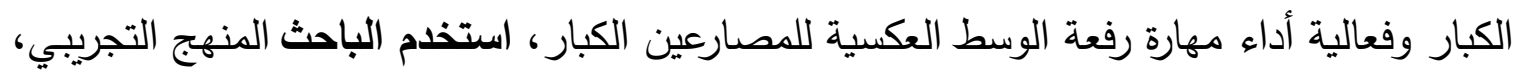

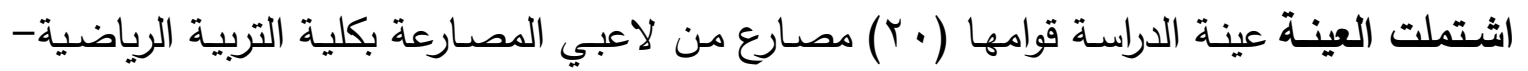

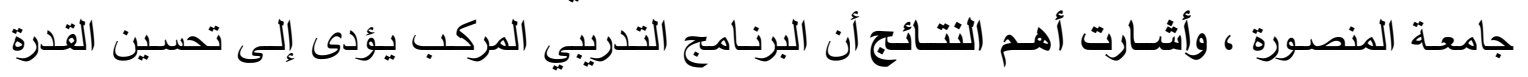

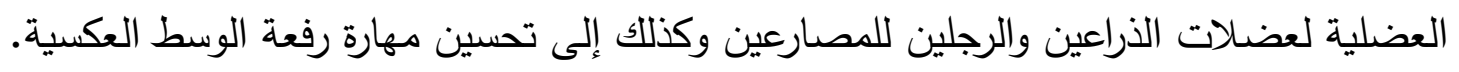

$$
\text { إجر اعهج البحث: }
$$

استخدم الباحث المنهج التجريبي وذلك لملائمة لطبيعة البحث وإجراءاته

$$
\text { مجتمع وعينة البحث : مالبث }
$$

تم اختيار عينة البحث بالطريقة العددية وبلغ قوامها (1 ( ) مصارعا وتم تقسيمهم إلى مجموعتين

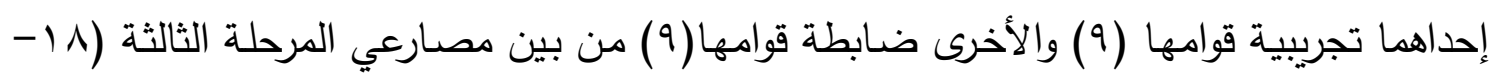

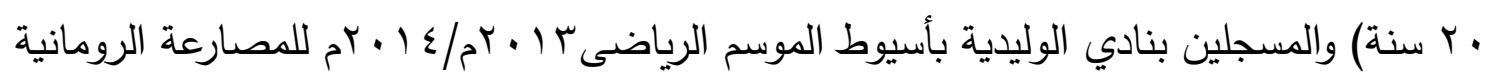

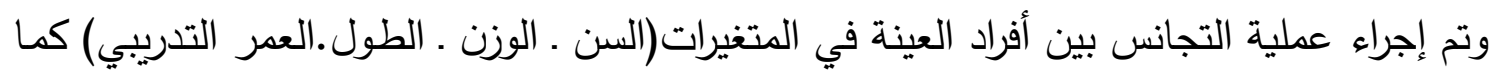

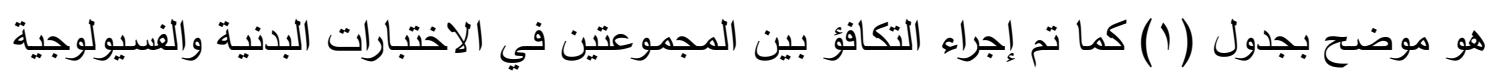

والمهارية كما هو موضح بجدول (r) . 


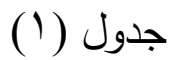

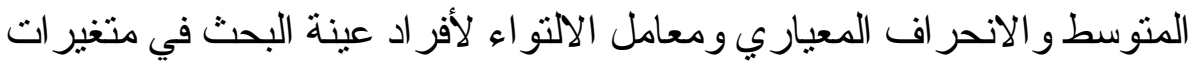

(السن ـ الوزن ـ الطول.العمر التدريبي)

( $1 \wedge=\dot{0})$

\begin{tabular}{|c|c|c|c|c|}
\hline \multirow{2}{*}{ معامل الالتواء } & \multicolumn{2}{|c|}{ أفراد العينة قيد البحث } & \multirow{2}{*}{ المتغيرات } & \multirow{2}{*}{ p } \\
\hline & $\varepsilon \pm$ & 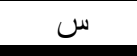 & & \\
\hline 0.08 & 0.49 & 18.88 & العمر الزمني (سنة) & 1 \\
\hline 0.47 & 0.86 & 4.37 & العمر التذريبي (سنة) & $r$ \\
\hline 0.76 & 6.68 & 70.75 & الوزن (كجم) & $r$ \\
\hline 0.51 & 5.30 & 168.62 & الطول (سم) & ؛ \\
\hline
\end{tabular}

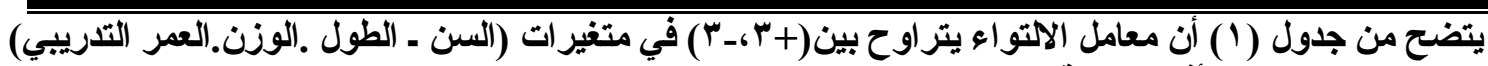

مما يدل على تجانس أفر اد العينة.

جدول (r)

دلالة الفروق بين منوسطات القياسات القبلية للمجمو عتين التجرييية و الضابطة في المتغير ات البدنية

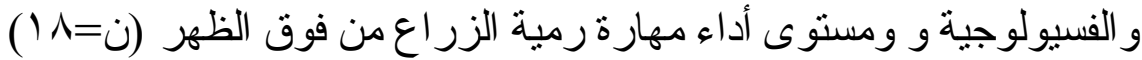

\begin{tabular}{|c|c|c|c|c|c|c|c|c|}
\hline \multirow{2}{*}{ الإلالة } & \multirow{2}{*}{ قالميمة (ت) } & \multicolumn{2}{|c|}{ المجمو عة التجريبية } & \multicolumn{2}{|c|}{ المجموعة الضابطة } & \multirow{2}{*}{ 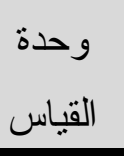 } & \multirow{2}{*}{ القياسات } & \multirow{2}{*}{ المتغيرات } \\
\hline & & $\varepsilon^{+-}$ & س س & $\varepsilon^{+-}$ & س - س & & & \\
\hline غير دال & 0.17 & 1.09 & 10.22 & 0.92 & 9.88 & ثانية & 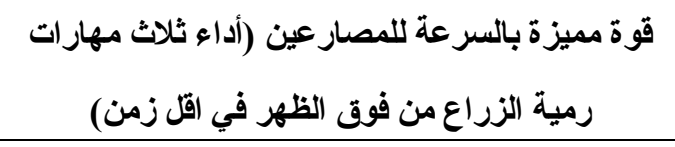 & \\
\hline غير دال & 0.10 & 1.66 & 13.44 & 0.70 & 12.66 & عدد & الجممل الرفعة المميتة) الميزة بالسرعة لعضلات & 承 \\
\hline غير دال & 0.22 & 1.50 & 12.44 & 1.05 & 11.88 & عدد & تحمل القوة المميزة بالسرعة للعضلات العاملة في & \\
\hline غير دال & 0.15 & 1.30 & 67.77 & 2.06 & 68.44 & ن/ق & النبض في الراحة & \\
\hline غير دال & 0.28 & 8.22 & 217.77 & 8.80 & 216 & ن/ق & النبض بعد (اق) & \\
\hline غير دال & 0.23 & 7.61 & 187.55 & 12.45 & 191.55 & نقل & النبض بعد( (ق)) & $\frac{9}{3}$ \\
\hline غير دال & 0.35 & 12.90 & 167.33 & 15.33 & 170.44 & ن/ق & النبض بعد("اق) & fูi \\
\hline غير دال & 0.42 & 299.23 & 3349.6 & 173.2 & 3377.3 & مليلتر & السعة الحيوية & \\
\hline غير دال & 0.33 & 0.47 & 8.04 & 0.36 & 7.94 & درجة & $\begin{array}{c}\text { فعالية أداء مهارة رمية الزراع من فوق } \\
\text { الظهر(حكام مقيمين) }\end{array}$ & 变 \\
\hline
\end{tabular}

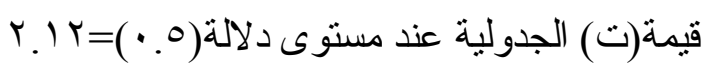

يتضح من جدول (ז) عدم وجود فروق دالة إحصائيا عند مستوى دلالة (0. •) في المتغير ات البننية و الفسيولو جية و المهاريـة قيد 


$$
\text { أدوات جمع البيانات : - الدات }
$$

1- الأدوات والأجهزة المستخدمة:

$$
\text { - جهاز الرستاميتر Restameter لقياس الطول والوزن (سم- كجم). }
$$

- جهاز الأسبيروميتر الجاف قياس السعة الحيوية ( VC ) الجاف Spiro metric -

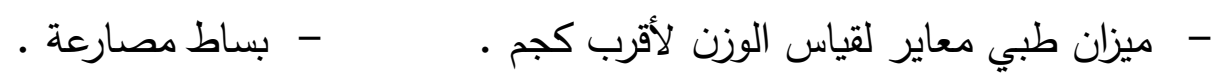

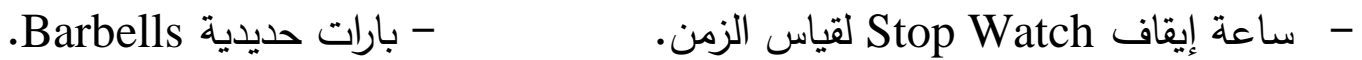

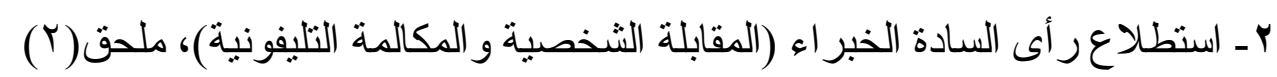

r ـ استمارة تسجيل بيانات اللاعبين، ملحق (1 (1).

ع - الاختبارات المستخدمة ،ملحق( ب ) :

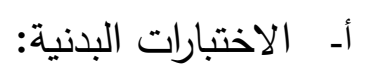

- القـوة المميـزة بالسـرعة للمصــارعين (أداء مهـارة رميـة الـزراع مـن فـوق الظهـر ثـلاث مـرات

$$
\text { في اقل وقت ممكن)،( اعداد الباحث). }
$$

- تحمل القوة المميزة بالسرعة لعضلات الجسم(الرفعة الميتة)( آل).

- تحمل القوة المميزة بالسرعة للعضلات العاملة في مهارة رمية الزراع من فوق الظهر ، الصميم الباحث).

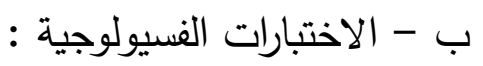

- قياس معدل النبض ( في الراحة ، بعد ادقيقة ، بعد كدقيقة ، بعد بدقيقة ) ( 1 (1).

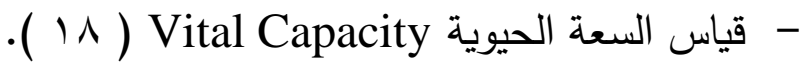
ج - الاختبارات المهارية :

- فعالية أداء مهارة رمية الزراع من فوق الظهرخلال( • بث)،( إعداد الباحث )(حكام مقيمين)، الفعالية العامة= $\quad$ الاتية: $\quad$ عدد النقاط المسلة المنفذة مع تطبيق معادلة الفاعلية الآتية: مهارة التراع

(Y०I:IV)

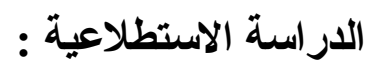

قام الباحث بإجراء دراسة استطلاعية على عينة قوامها (· مصارع) وتم اختيارهم بالطريقة

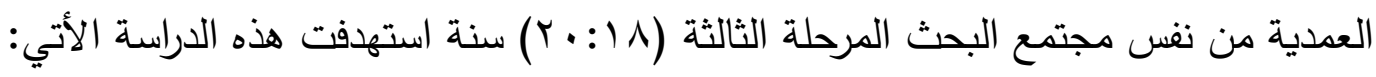

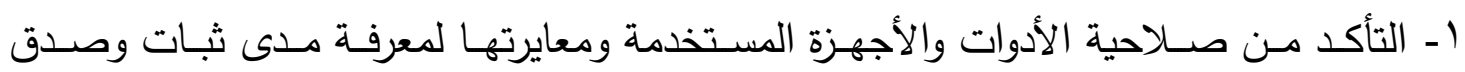
استخدامها في قياس ما وضعت من اجله والمكان المستخدم لتنفيذ البرنامج. r - مدى فهم واستيعاب الأيدي المساعدة لواجباتهم ومهامهم، بلغ عددهم(ب آ مساعدين)

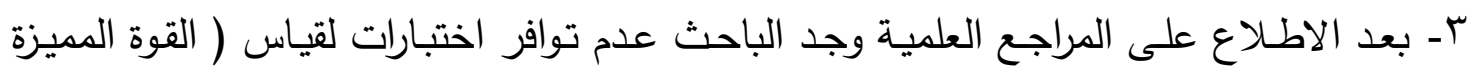

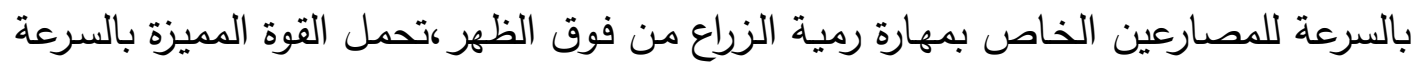
للعضـلات العاملـة بمهارة رمية الزراع من فوق الظهر ، فقد قام الباحث بتصميم اختبارين 
لقياسـهما ، وتم تطبيق المعـاملات العلميـة (الصـدق والثبات ) للاختبـار للتأكد مـن مدى صلاحيته للقياس.

أولا - ثبات الاختبارات البدنية و الفسيولوجية و المهارية قيا البحث:

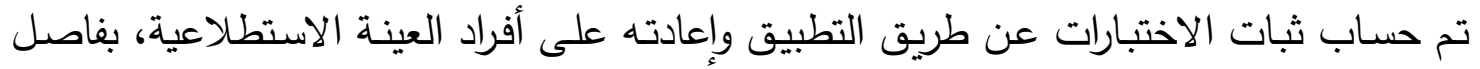

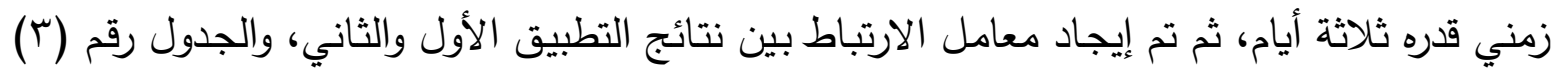

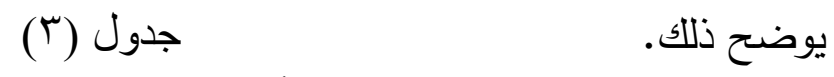

معامل الارتباط بين التطبيق الأول و التطبيق الثاني للاختبار ات البدنية و الفسيولوجية و المهارية قيد

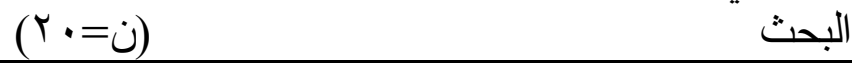

\begin{tabular}{|c|c|c|c|c|c|c|c|}
\hline \multirow{2}{*}{ قالمسة (ر ) } & \multicolumn{2}{|c|}{ التطبيق الثاني } & \multicolumn{2}{|c|}{ التطبيق الأول } & \multirow{2}{*}{ | القياس } & \multirow{2}{*}{ القياسات } & \multirow{2}{*}{ المتغير ات } \\
\hline & $\varepsilon^{+}$ & س & $\varepsilon^{+}$ & س & & & \\
\hline 0.6210 & 1.12 & 10.3 & 0.99 & 9.95 & ثانية & 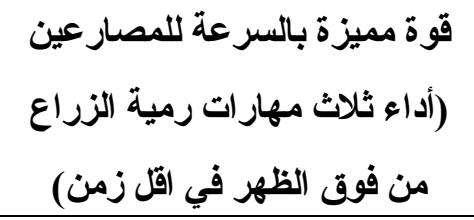 & \\
\hline 0.6353 & 1.59 & 12.85 & 1.51 & 13.1 & عدد & تعضلات القوم المميزة بالسرعة & البلنية \\
\hline 0.7810 & 1.02 & 14.1 & 1.46 & 14.4 & عدد & 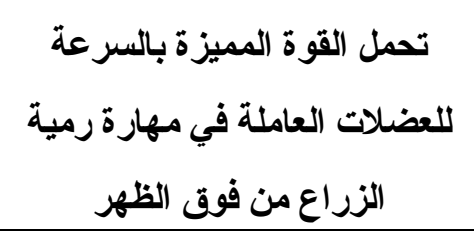 & \\
\hline 0.9433 & 2.45 & 65.95 & 3.82 & 64.7 & نلق & النبض في الراحة & \\
\hline 0.8891 & 7.72 & 217.4 & 8.88 & 219.95 & ن نق & النبض بعد (اق) & \\
\hline 0.7853 & 7.97 & 188.05 & 7.04 & 189.75 & نقل & النبض بعد(بق) & اله \\
\hline 0.8403 & 8.75 & 169.05 & 8.91 & 170.35 & ن نق & النبض بعد(بق) & \\
\hline 0.5617 & 230.00 & 3347.65 & 223.25 & 3367.1 & |مليلتر & السعة الحيوية & \\
\hline 0.6042 & 0.37 & 8.12 & 0.36 & 7.95 & | درجة & فع فعالية أداء مهارة رمية الزراع الظهر (حكام مقيمين) & المهارية \\
\hline
\end{tabular}

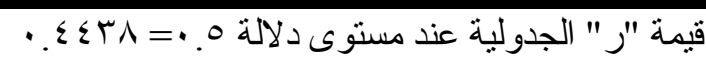

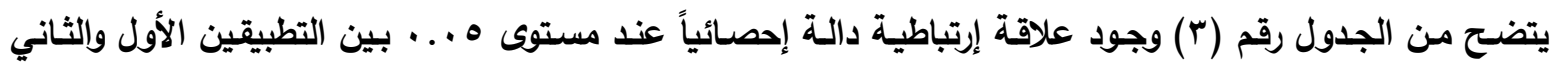
للاختبارات البدنية والفسيولوجية والمهارية قيد البحث مما يثير إلى ثبات هذه الاختبارات عند إجراء القياس التياس 


$$
\text { ثانيا- صدق الاختبارات البدنية و الفسيولوجية و المهارية قيد البحث: }
$$

قام الباحث باستخدام صدق التمايز للتعرف على مدى صدق الاختبارات المستخدمة في التعرف ولارف

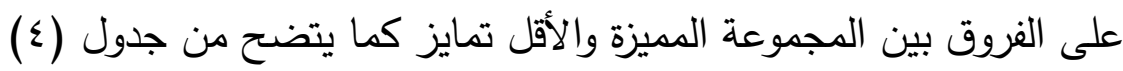

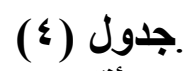

دلالة الفروق بين المجموعتين المميزة والأقل تمايز في المتفيرات البلنية والفسيولوجية

\begin{tabular}{|c|c|c|c|c|c|c|c|c|}
\hline \multirow{2}{*}{ الإحصائية } & \multirow{2}{*}{ قالمية (ت) } & \multicolumn{2}{|c|}{ المجمو عة الأقل تمايز } & \multicolumn{2}{|c|}{ المجمو عة الممبزة } & \multirow{2}{*}{ وحدة } & \multirow{2}{*}{ القياسات } & \multirow{2}{*}{ المتغير ات } \\
\hline & & $\varepsilon^{+}$ & س - س & $\varepsilon^{+}$ & س - س & & & \\
\hline دال & 9.87 & 0.08 & 11.94 & 0.46 & 9.66 & ثانية & 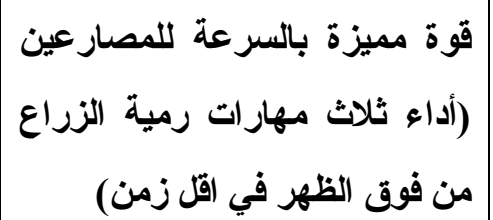 & \\
\hline دال & 6.39 & 0.54 & 7.6 & 0.89 & 15.6 & عداد & 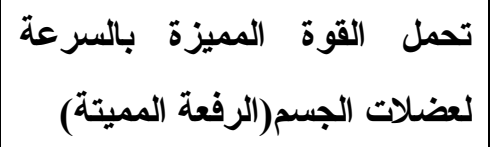 & البانية \\
\hline 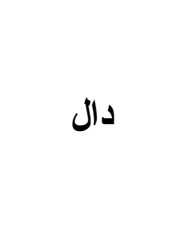 & 7.42 & 0.83 & 7.2 & 0.89 & 15.4 & عداد & لعصلات العاملة في مهارة رمية الميزة بالسرعة & \\
\hline 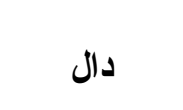 & 8.43 & 1.30 & 74.2 & 2 & 61 & ن/ق & النبض في الراحة & \\
\hline 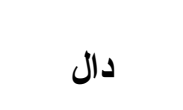 & 7.71 & 5.47 & 244 & 9.81 & 208.6 & ن/ق & النبض بعد (اق) & \\
\hline دال & 9.32 & 6.06 & 240.6 & 10.18 & 181.8 & ن/ق & النبض بعد( (ق)) & \\
\hline دال & 7.23 & 4.33 & 197.6 & 4.43 & 168.8 & ن/ق & النبض بعد(بق) & \\
\hline دال & 6.97 & 223.22 & 2976 & 174.92 & 3910 & مليلتر & السعة الحيوية & \\
\hline 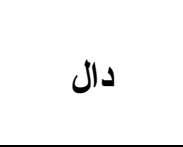 & 7.55 & 0.83 & 6.8 & 1.14 & 9.6 & درجة & فعالية اداء مهارة رمية الزراع من & المهارية \\
\hline
\end{tabular}

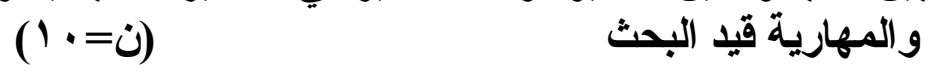

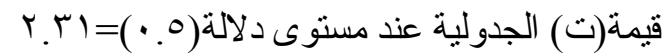

يتضـح من الجدول رقم (؛ ) وجود فروق دالـة إحصـائياً عند مستوى دلالـة ه ه. , · بين المجموعتين المميزة

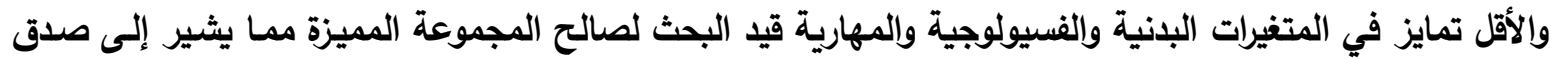
هذه الاختبارات فيما تقيس . 


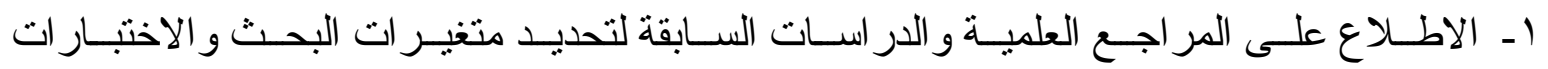
المناسبة لتلك المتغير ات. r- استطلاع ر أى الخبر اء عن طريق المقابلة الثخصية و المكالمـة التليفونيـة لتحديد متغير ات البحث و الاختبار ات المناسبة لها، ملحق(r). بـ إجر اء الدر اسة الاستطلاعية لمعرفة مدى صلاحية الأدو ات و الأجهزة و الاختبار ات المستخدمة في

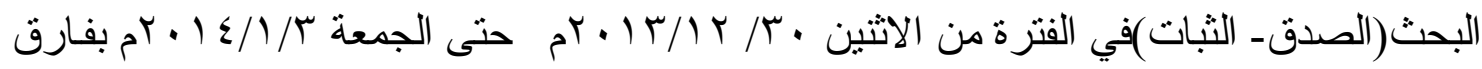
زمني ثلاث أيام بين التطبيق الأول و التطبيق الثاني.

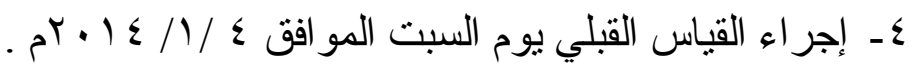

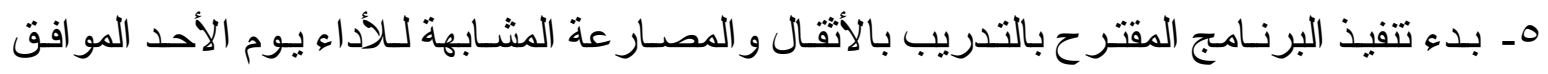

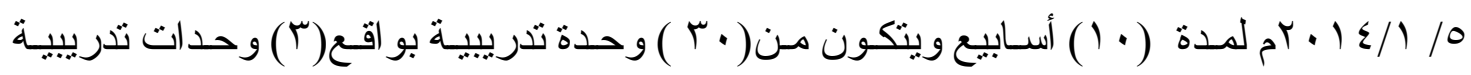
أسبو عيا (الأحد/الثثلاثاء/الخميس) ، زمن الوحدة التدريبية يتر اوح مـابين ( • 7. • 9) دقيقة ، طريقة

$$
\text { التدريب( الفترى منخفض ومرتفع الثدة )، ملحق (ع ). }
$$

اـ ـ تتفيذ البرنامج على المجموعة الضابطة بدون التدريبات المقترحة للأثقال وفى نفس توقيت تتفيذ البرنامج المقترح على المجمو عة التجريبية.

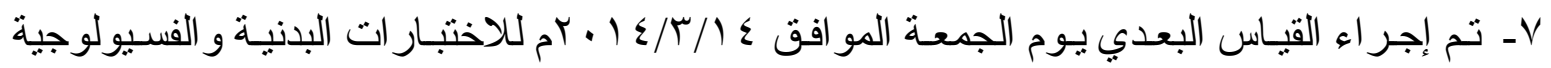
و المهارية قبد البحث.

\section{المعالجات الإحصائية:}

استخدم الباحث المعالجات الإحصائية التالية :

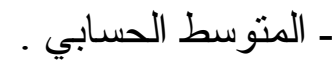

ـ الانحر اف المعيار ي .

- اختبار Test

ـ معامل الارتباط .

ـ معامل الالتو اء.

ـ الفرق بين المتوسطين. 


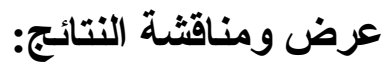

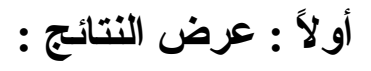

سوف يتم عرض النتائج حسب ترتيب الفروض:

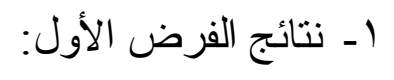

\section{(0) (0)}

دلالة الفروق بين متوسطات القياسين القبلي والبعدي للمجموعة التجريبية في المتغيرات البلنية قيد البحث

\begin{tabular}{|c|c|c|c|c|c|c|c|c|c|}
\hline \multirow{2}{*}{ الإحصائية } & \multirow{2}{*}{ 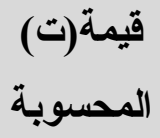 } & \multirow{2}{*}{ المتوق بين } & \multicolumn{2}{|c|}{ القياس البعدى } & \multicolumn{2}{|c|}{ القياس القبلي } & \multirow{2}{*}{ وحدة } & \multirow{2}{*}{ القياسات } & \multirow{2}{*}{ لمتغير ات } \\
\hline & & & $\varepsilon^{+}$ & س س & $\varepsilon^{+}$ & س & & & \\
\hline دال & 6.53 & $r .07$ & 0.86 & 6.66 & 1.09 & 10.22 & ثانية & ( قوة مميزة بالسرعة للمصارث مهار رمية الزراعين & البدنية \\
\hline دال & 6.94 & r.TV & 1.36 & 17.11 & 1.66 & 13.44 & عدد & تعضلات الجسم( الرفعة المميتة) & \\
\hline دال & 8.74 & $\varepsilon$ & 0.72 & 16.44 & 1.50 & 12.44 & عدد & 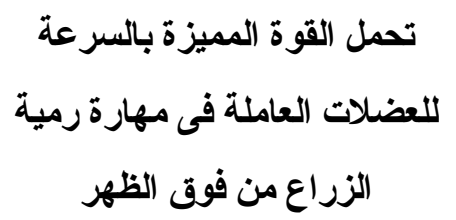 & \\
\hline
\end{tabular}
$(q=\dot{0})$

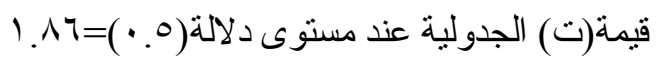

يتضـح مـن الجدول رقم (5) وجود فروق ذات دلالـة إحصـائية بين القياسين القبلي و البعدي للمجمو عة التجريية في المتغير ات البدنية قيد البحث حيث قيمة (ت) المحسوبة أكبر من قيمتها الجدولية التية

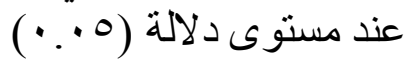




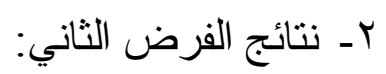

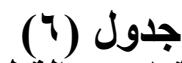

دلاكة الفروق بين متوسطات القياسين القبلي والبعدي للمجموعة التجريبية في المتغير ات اتبوات

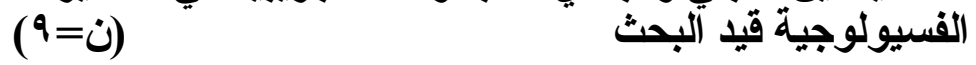

\begin{tabular}{|c|c|c|c|c|c|c|c|c|c|}
\hline \multirow{2}{*}{ الإحصالة } & \multirow{2}{*}{ قيمة(ت) } & \multirow{2}{*}{ الفرق بين } & \multicolumn{2}{|c|}{ القياس البعدى } & \multicolumn{2}{|c|}{ القياس القبلي } & \multirow{2}{*}{ وحدة القياس } & \multirow{2}{*}{ القياسـات } & \multirow{2}{*}{ المتغير ات } \\
\hline & & & $\varepsilon^{+}$ & س & $\varepsilon^{+}$ & س - س & & & \\
\hline دال & 9.95 & $V . \varepsilon \varepsilon$ & 2.29 & 60.33 & 1.30 & 67.77 & ن/ق & النبض فى الر احة & \\
\hline دال & 7.41 & 15.00 & 4.49 & 204.22 & 8.22 & 217.77 & نلق & النبض بعد (اق) & \\
\hline 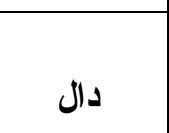 & 6.46 & $1 \cdot . \vee \wedge$ & 8.80 & 176.77 & 7.61 & 187.55 & ن/ق & النبض بعد(rق) & الفسيولوجية \\
\hline 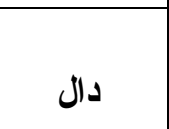 & 9.6 & T. & 12.90 & 161 & 12.90 & 167.33 & نلق & النبض بعد(سق) & \\
\hline دال & 7.87 & $v \cdot \Lambda .11$ & 395.27 & 4057.77 & 299.23 & 3349.66 & مليلتر & السعة الحيوية & \\
\hline
\end{tabular}

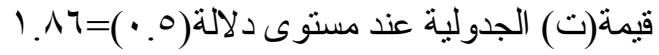

يتضح من الجدول رقم (7) وجود فروق ذات دلانة إحصائية بين القياسين القبلي و البعدي للمجموعة التجريبية

في المتغير ات الفسيولوجية قيد البحث حيث قيمة (ت) المحسوبة أكبر من قيمتها الجدولية عند مستوى دلالة (ه . . ).

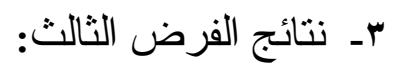

(V) جدول

دلالة الفروق بين متوسطات القياسين الفبلي والبعدي للمجموعة التجريبية في المتغيرات المهارية قيد ألبحث

\begin{tabular}{|c|c|c|c|c|c|c|c|c|c|}
\hline \multirow{2}{*}{ الإحلامة } & \multirow{2}{*}{ قيمة(ت) } & \multirow{2}{*}{ الفتوسط بين } & \multicolumn{2}{|c|}{ القياس البعدى } & \multicolumn{2}{|c|}{ القياس القبلي } & \multirow{2}{*}{ وحدة } & \multirow{2}{*}{ القياسـات } & \multirow{2}{*}{ لمتغيرات } \\
\hline & & & $\varepsilon^{+}$ & س & $\varepsilon^{+}$ & س & & & \\
\hline دال & 9.15 & $\overline{T .1 \leq}$ & 0.75 & 11.18 & 0.47 & 8.04 & درجة & فع فعالية اداء مهارة رمية الزراع الظهر(حكام مقيمين) & المهارية \\
\hline
\end{tabular}

قيمة(ت) الجدولية عند مستوى دلالة(0. •)=17.

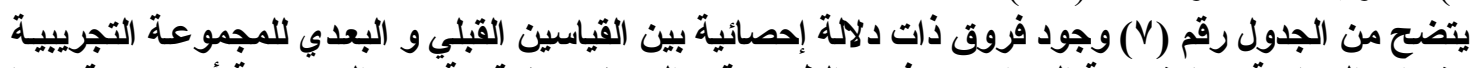

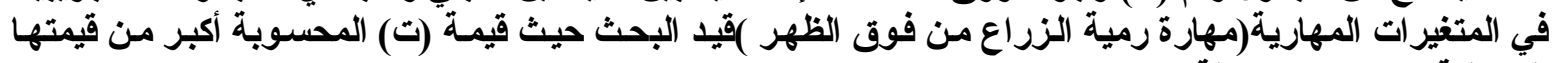

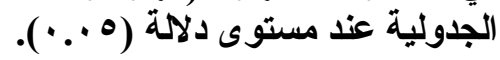




\section{جدول (^)}

دلالة الفروق بين متوسطات القياسين البعديين للمجموعة التجريبية والضابطة في المتغيرات البنية

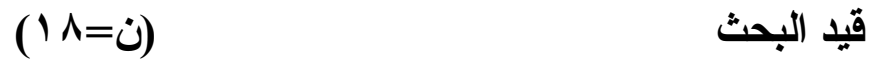

\begin{tabular}{l|c|c|c|c|c|c|c|c|c}
\hline \hline & \\
\hline
\end{tabular}

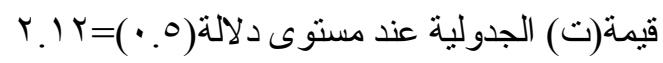

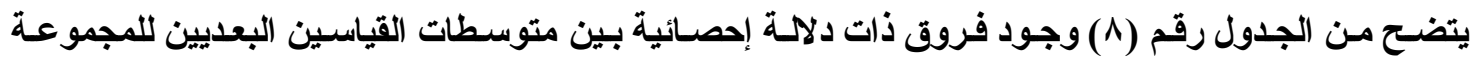
التجريبية و الضابطة في المتغيرات البانية قيد البحث حيث قيمة (ت) المحسوبة أكبر من قيمتها الجدولية عند مستوى دلالة (•. (•). 


\section{(9) (9)}

دلالة الفروق بين متوسطات القياسين البعديين للمجموعة التجريبية و الضابطة في المتغيرات

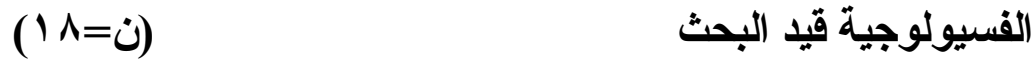

\begin{tabular}{|c|c|c|c|c|c|c|c|c|c|}
\hline \multirow{2}{*}{ الإحصائية } & \multirow{2}{*}{ قيمة(ت) } & \multirow{2}{*}{ الفرق بين } & \multicolumn{2}{|c|}{ المجموعة التجريبية } & \multicolumn{2}{|c|}{ المجموعة الضابطة } & \multirow{2}{*}{ وحدة } & \multirow{2}{*}{ القياسات } & \multirow{2}{*}{ المتغير ات } \\
\hline & & & $\varepsilon^{+}$ & س & $\varepsilon^{+}$ & س & & & \\
\hline دال & 6.65 & 7.00 & 2.29 & 60.33 & 2.31 & 66.88 & ن/ق & النبض فى الر احة & \\
\hline دال & 8.68 & $1 \leq . \mu T$ & 4.49 & 204.22 & 8.22 & 218.55 & ن/ق & النبض بعد & \\
\hline دال & 5.61 & 14 & 7.14 & 175.33 & 5 & 188.33 & ن/ق & بعد(بق) & الفسيولوجية \\
\hline دال & 7.81 & IY.VY & 12.90 & 161 & 12.42 & 173.77 & ن/ق & بعد(بق) & \\
\hline دال & 6.92 & 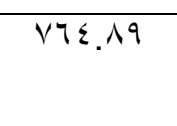 & 395.27 & 4057.77 & 162.33 & 3292.88 & مليلتر & السعة الحيوية & \\
\hline
\end{tabular}

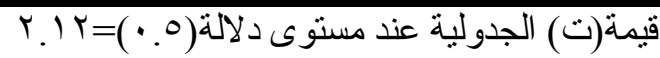

يتضـح مـن الجدول رقم (†) وجـود فروق ذات دلاــة إحصـائية بين القياسـين البعديين للمجموعـة التجريبيـة و الضابطة في المتغيرات الفسيولوجية قيد البحث حيث قيمـة (ت) المحسوبة أكبر من قيمتها الجدولية عند مستوى لهن دلالة (0. (•) (ن)

جدول (1) (1)

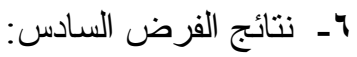

دلالة الفروق بين متوسطات القياسين البعديين للمجموعة التجريبية و الضابطة في المتغير ات $(1 \wedge=\dot{0})$

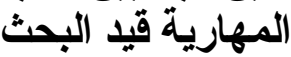

\begin{tabular}{c|c|c|c|c|c|c|c|c|}
\hline \hline & \\
\hline
\end{tabular}

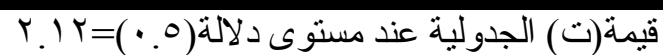

يتضـح مـن الجدول رقـم (V) وجـود فروق ذات دلاــة إحصـائية بين القياسين البعديين للمجموعـة التجريبيـة و الضابطة في المتغيرات المهارية(مهارة رمية الزراع من فوق الظهر )ثيد البحث حيث قيمة (ت) المحسوبة أكبر من قيمتها الجدولية عند مستوى دلالة (0 •. •). ثانياً : مناقشة التتائج : 
يتضح من الجدول رقم (0) وجود فروق دالـة إحصائية بين القياسـات القبلية و البعدية للمجموعة

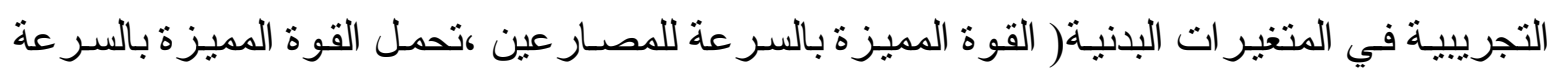

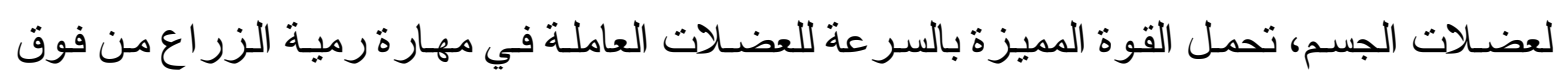

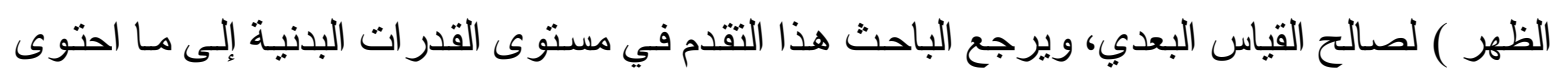

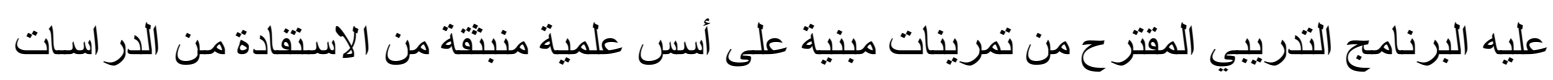

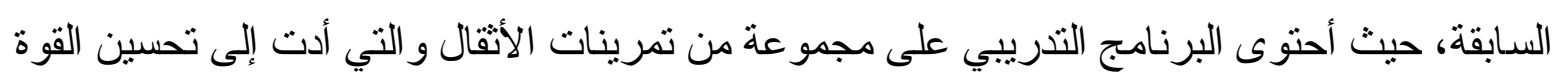

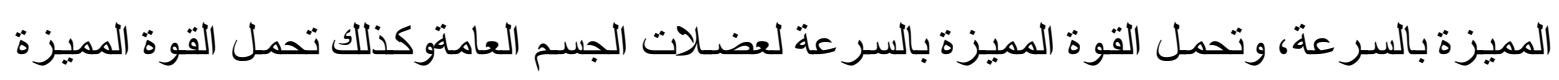

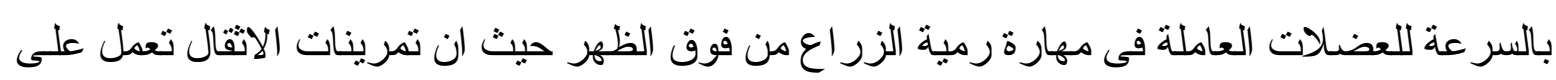

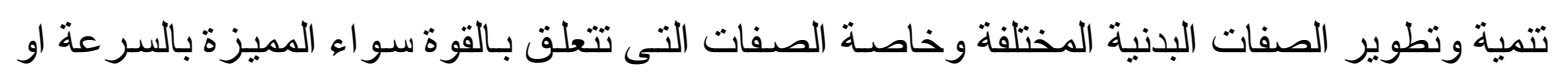
تحمل القوة.

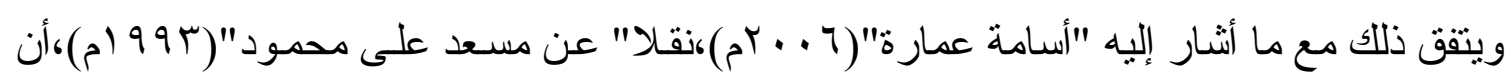

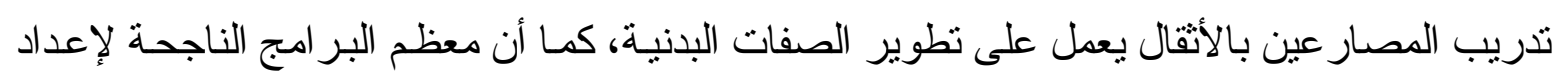

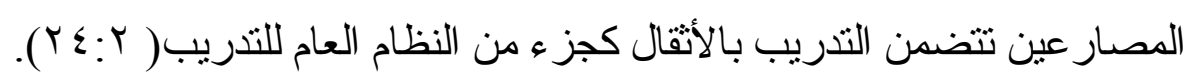

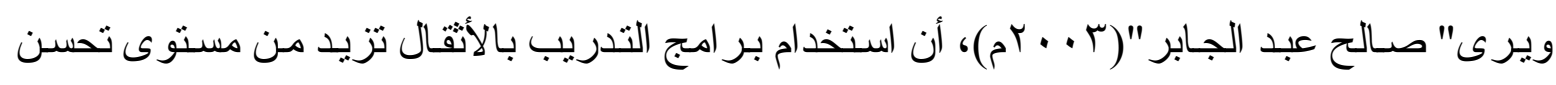

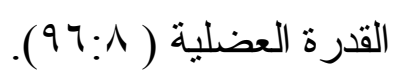

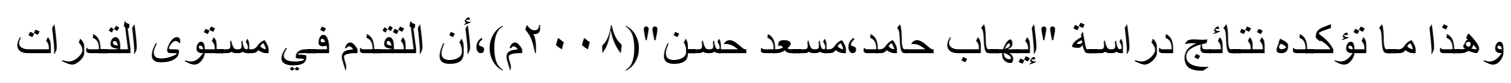

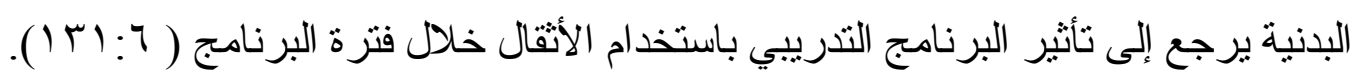

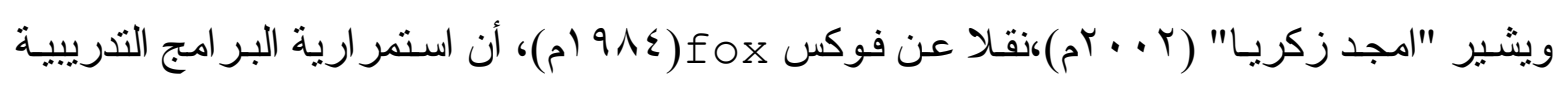

بالأثقال لمدة تفوق ستة أسابيع ذات تأثثر معنوي في زيادة القوة بأنو اعها المختلفة (

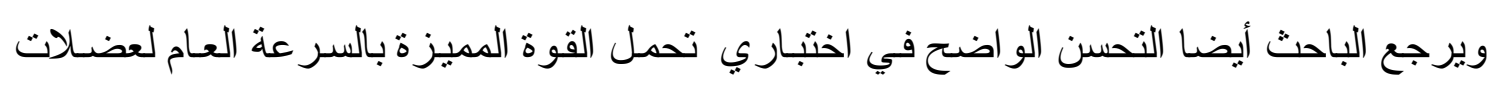

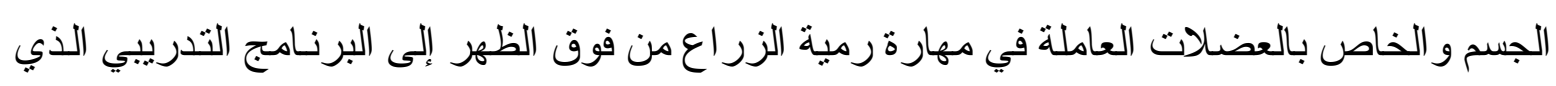

$$
\text { احتوى على تدريبات بالأثقال. }
$$

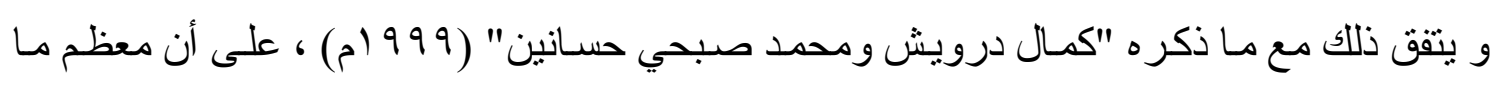

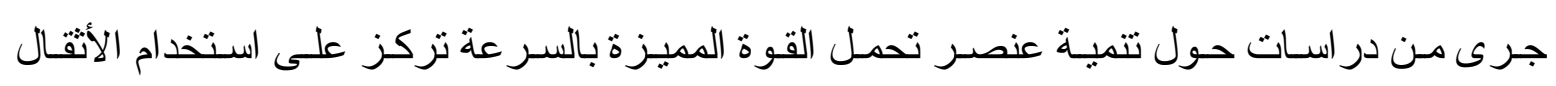

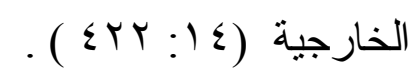

ويضيف بسطويسى أحمد (1999 (1) أن أهم طرق تدريب تحمل القوة الممبزة بالسرعة هو التدريب

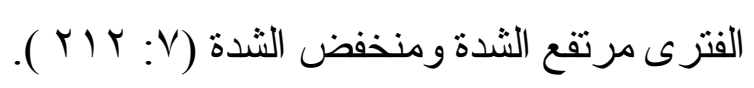

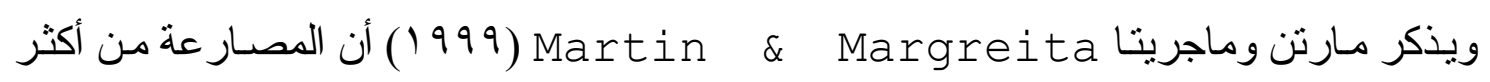

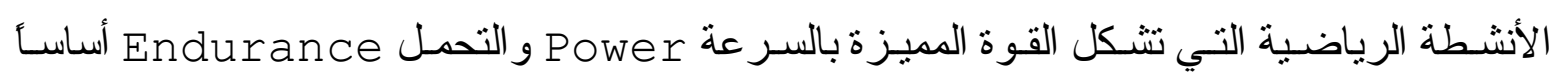


للأداء البذني الناجح وخاصة إذا نم المزج بين عنصر التحمل و القوة المميزة بالسر عة( تحمل القوة

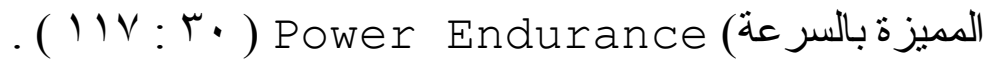
وبذلك يتحقق الفرض الأول و الذي ينص على: بالئ

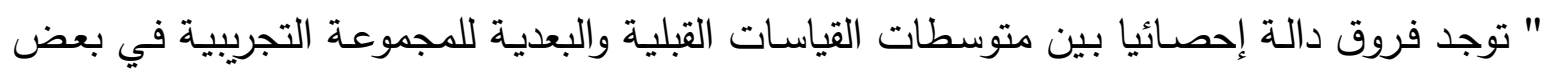

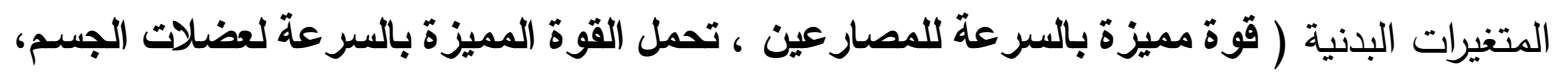

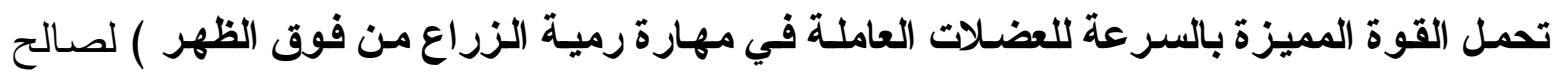

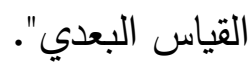

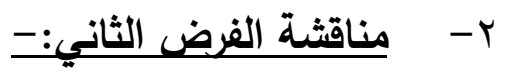

يتضح من الجدول رقم (†) وجود فروق دالة إحصائية بين القياسـات القبلية و البعديـة للمجمو عـة التجريبية في بعض المتغير ات الفسيولوجية قيد البحث (النبض في الراحة، النبض فئلئ بعد دقيقة، النبض

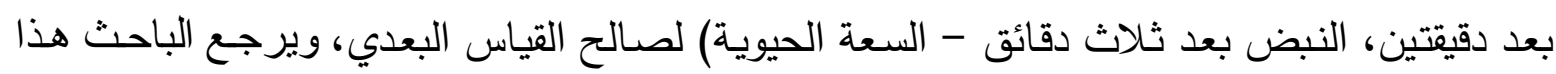
التقدم في مستوى تللك المتغير ات إلى تأثير البرنامج المقترح للتدريب بالأثقال.

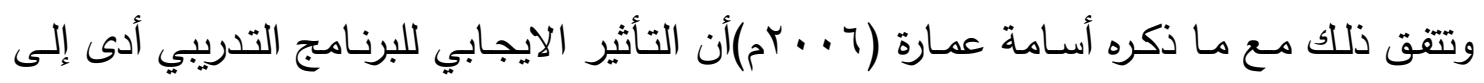

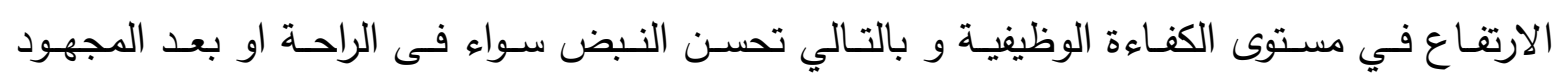
$\cdot(1 \cdot \varepsilon: r)$

كما يضيف نقلا عن "فاروق عبد الوهاب"(9901)،وأن التدريب المنتظم يؤدى إلى انخفاض في

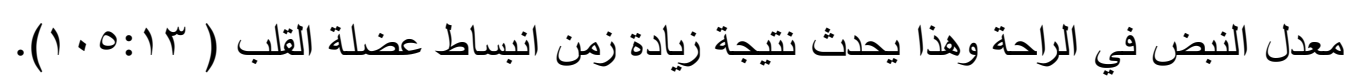

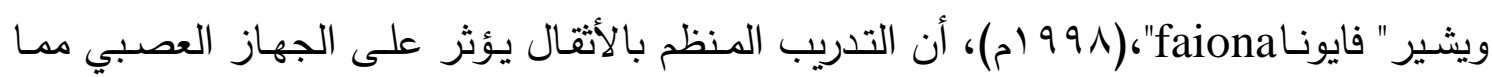

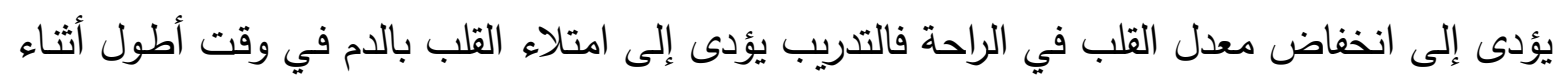

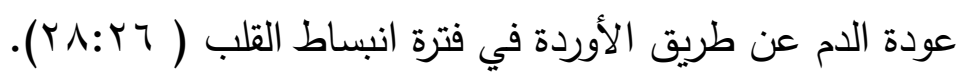

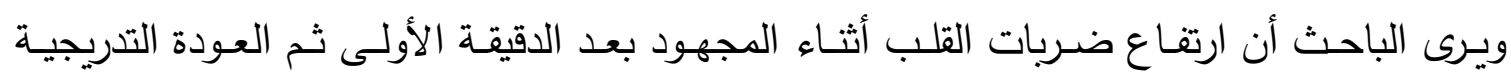

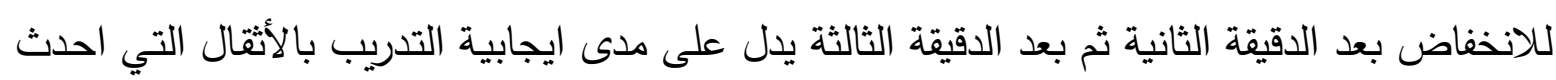

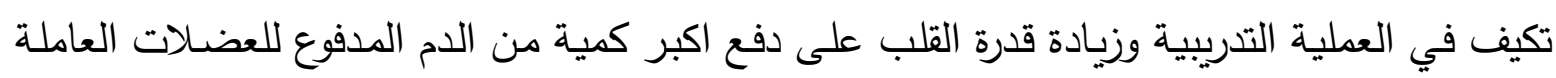
أثناء المجهود الواقع على العضلات لتمد العضلات العاملة بالاكسجين والغذاء الكافيين لتحمل الاداء

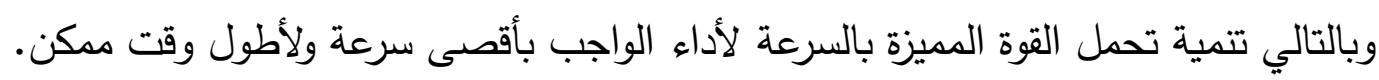

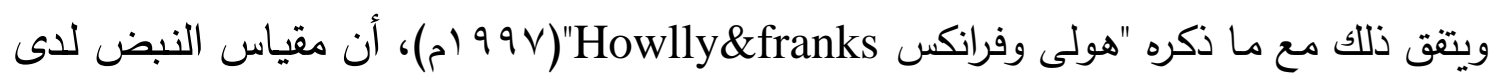

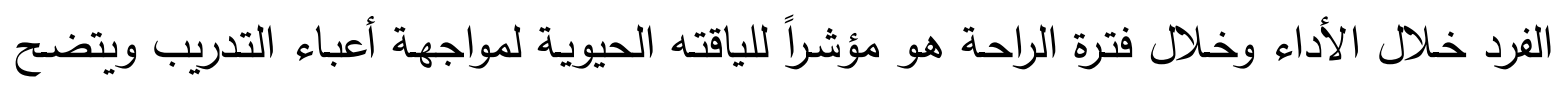

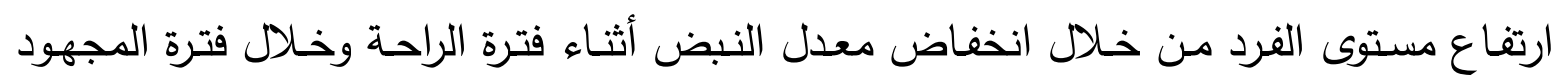
البدني (Y^)

ويرى الباحث أن التحسن في اختبار السعة الحيوية يرجع إلى البرنامج التدريبي للأثقال ، حيث ان

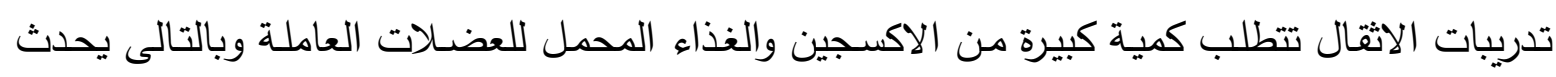
تكيف اثناء عملية التدريب لتوفير الاكسجين للعضلات للعمل لاكبر وقت مدكن وبكفاءة عالية 
وذلك ما أشـار إليه " السيد مصطفى "(r . . rم)، أن السعة الحيوية للرئتين تعتبر مكتسبة

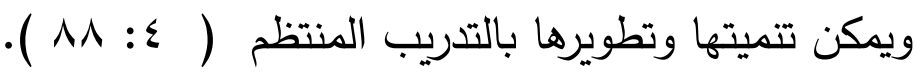

$$
\begin{aligned}
& \text { وبذلك يتحقى الفرض الثاني والذي ينص على على: }
\end{aligned}
$$

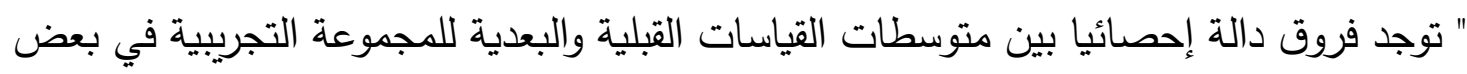

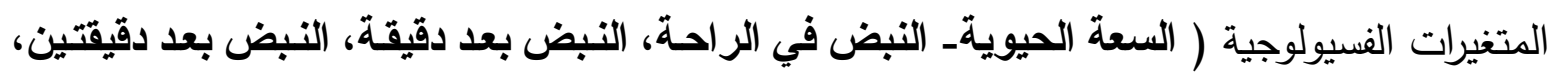
النبض بعد ثُلاث دقائق) لصالح القياس البعدي".

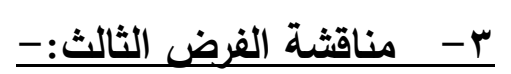

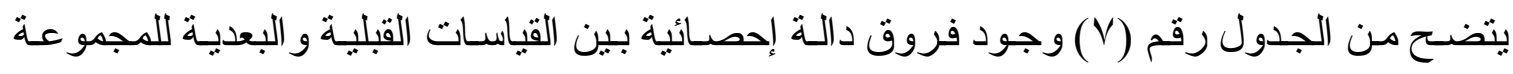

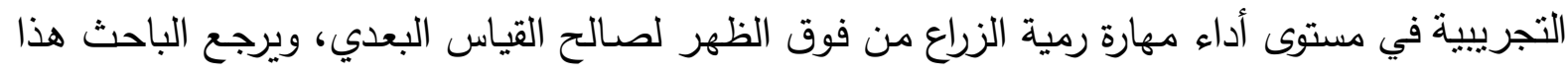

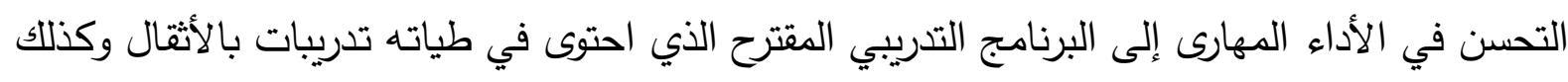

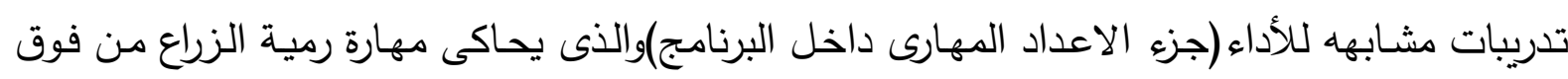
الظهر مع منافس سلبى ثم يتدرج فى الصعوبة حتى يصبح منافسا حقيقيا .

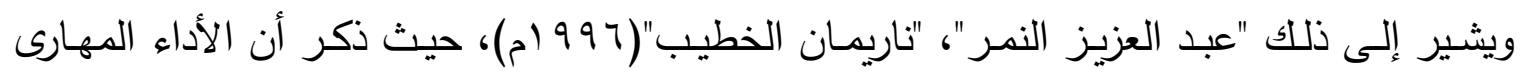

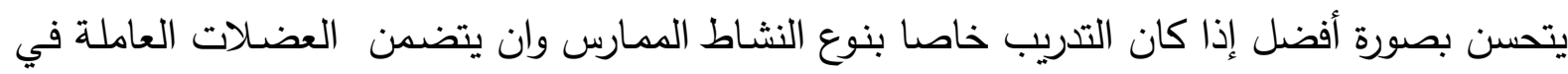

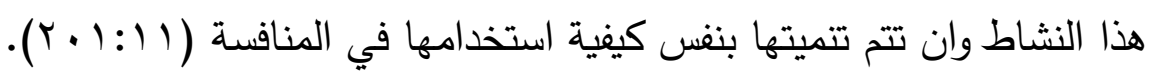

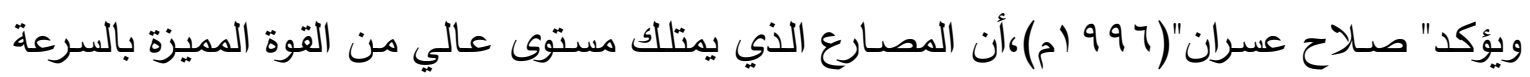

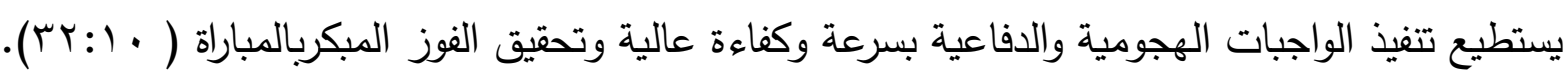

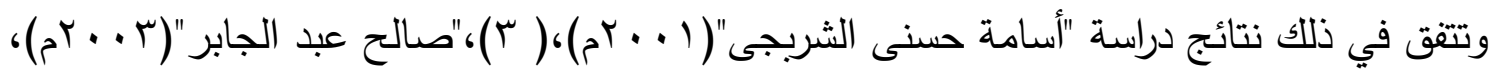

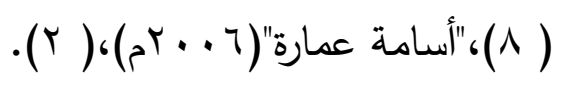

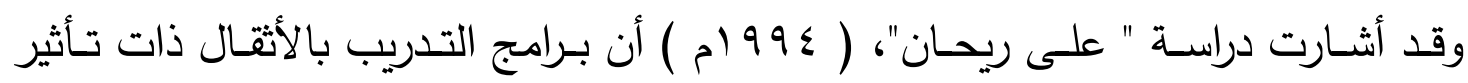

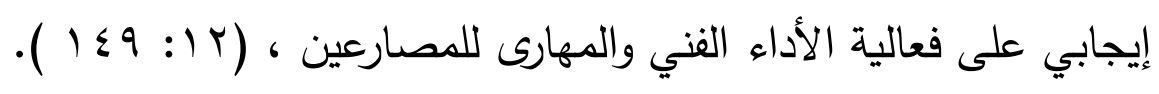

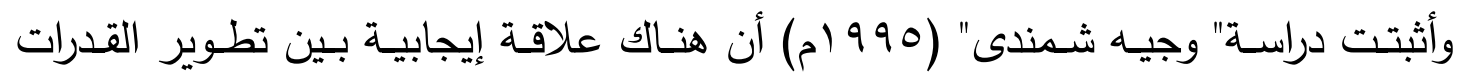

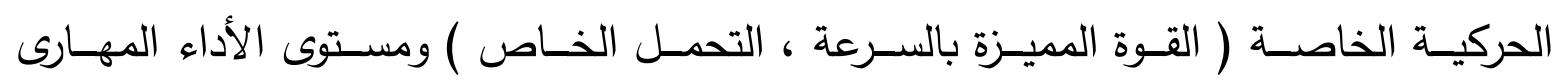

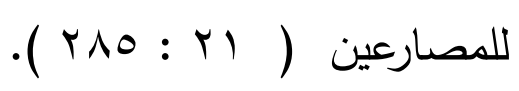

ويضيف "إيهاب حامد"،"مسعد حسن"(1 . ․ rم)،أن التقدم الذي حدث للمجموعة التجريبية

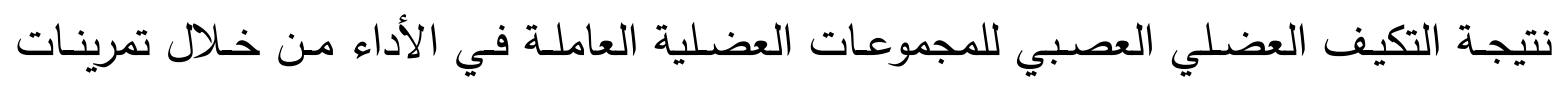

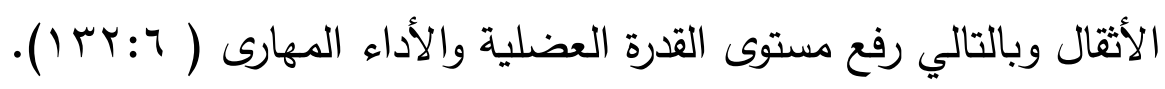

وبذلك يتحقق الفرض الثالث و الذي ينص على:

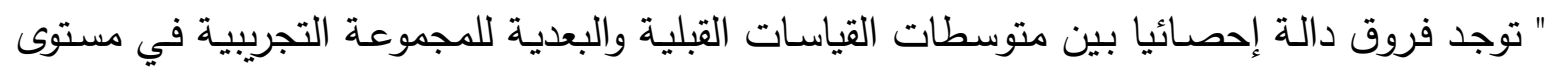
أداء مهارة رمية الزراع من فوق الظهر للمصارعين لصالح القياس البعدي". 
يتضح من الجدول رقم (^) وجود فروق دالة إحصائية بين القياسين البعديين للمجموعة التجريبية

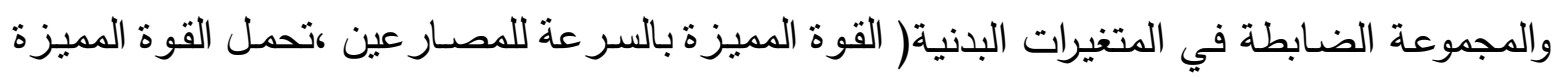

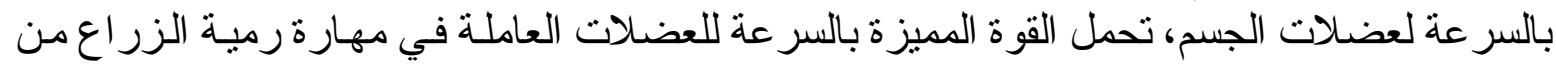
فوق الظهر ) لصالح الهجموعة التجريبية ويرجع الباحث هذا الفارق بين المجموعة الضابطة والتجريبية لان المجموعة التجريبية طبق عليها البرنامج التدريبي المقترح دون المجموعة الضابطة والذي يحتوى على تدريبات الأثقال والتى اثرت تاثيرا

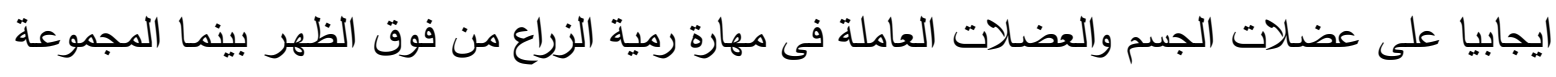
الضابطة لم يكن فى برنامجها التدريبى تدريبات الاتقال وذلك الذى احدث الفارق فى المستوى التدريبى.

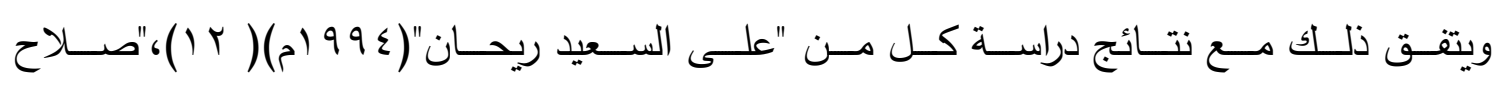

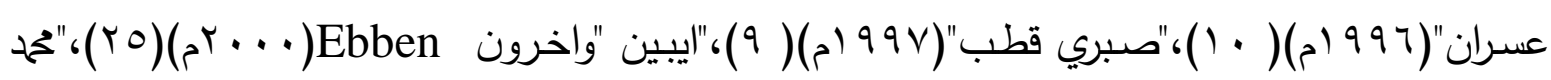

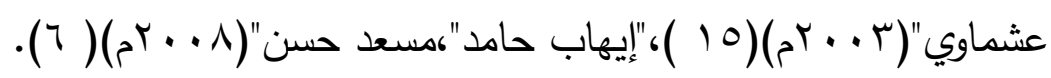

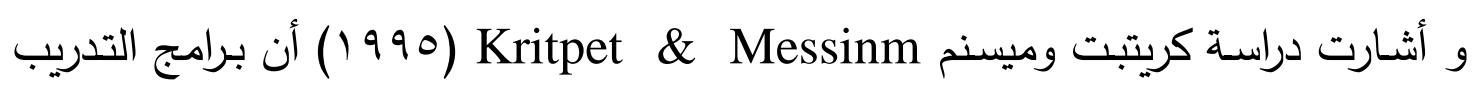

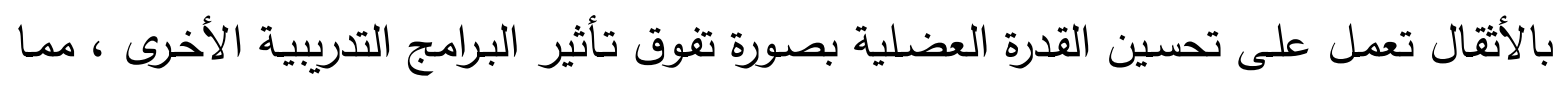

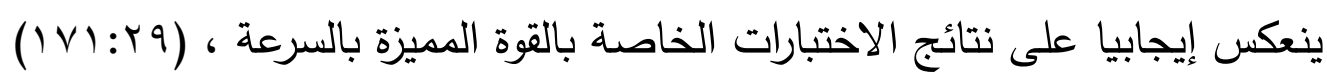
ويضيف مايهيو وآخرون Mayhew(990 (م) إلى وجود فروق معنوية بين القياسات القبلية

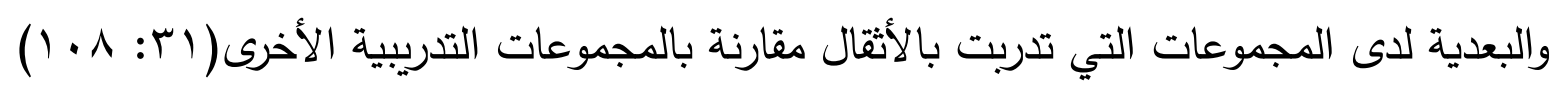

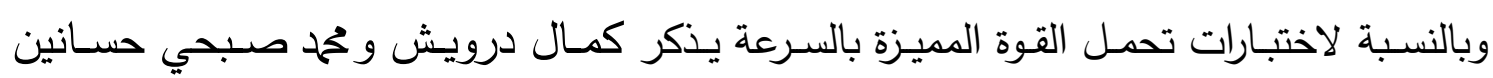
(999 (م) أن أهم الطرق المستخدمة في تدريب عنصر تحمل القوة المميزة بالسرعة هو التدريب

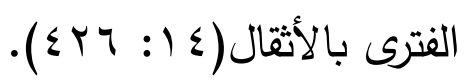
ويضيف " بسطويسى أحمد" (999 (م) انه يتم تتمية عنصر تحمل القوة المميزة بالسرعة

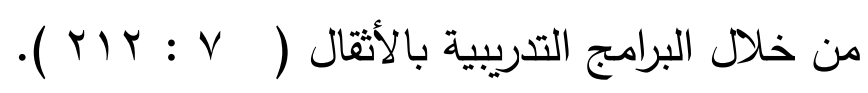

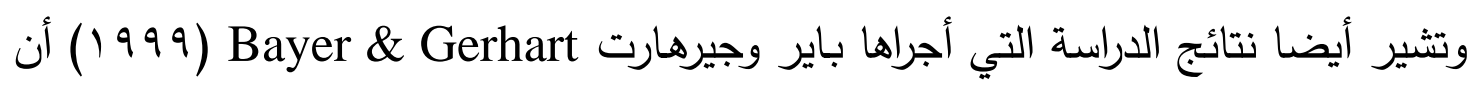

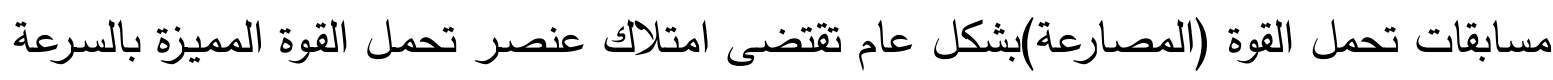

$$
\text { ،وذللك لإنتاج القوة الموظفة في اتجاه الأداء ( ب : : r ). }
$$

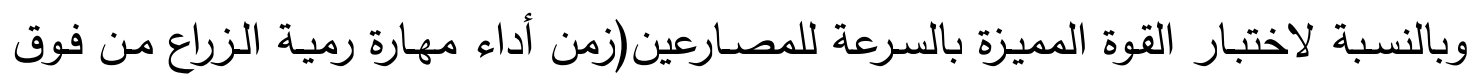

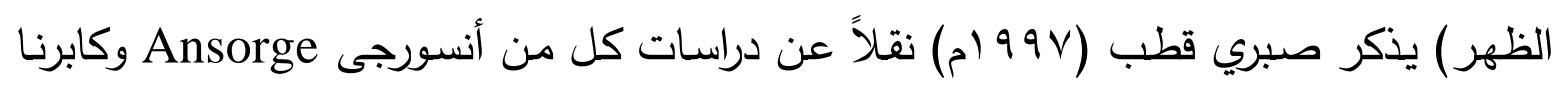
Kaberna

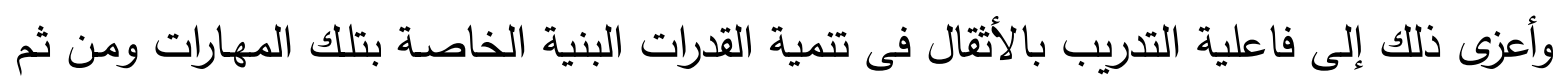

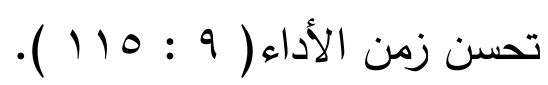
وبذلك يتحقى الفرض الرن ابع واه والذي ينص على: 
"توجد فروق دالة إحصائيا بين متوسطات القياسين البعديين للمجموعتين التجريبية والضابطة في

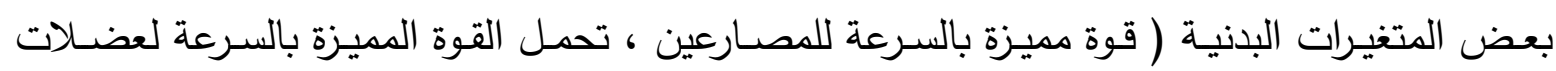

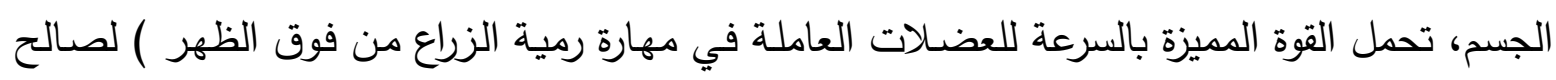
المجموعة التجريبية". ه-مناقشة الفرض الخامس:-

يتضح من الجدول رقم (9) وجود فروق دالة إحصائية بين القياسين البعديين للمجموعة التجريبية

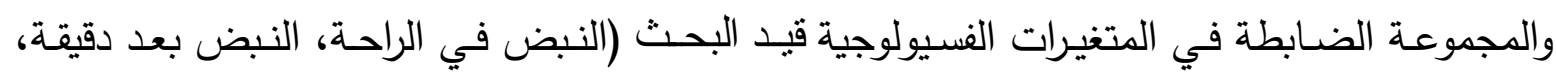
النبض بعد دقيقتين، النبض بعد ثلاث دقائق - السعة الحيوية) لصالح المجموعة التجريبية.

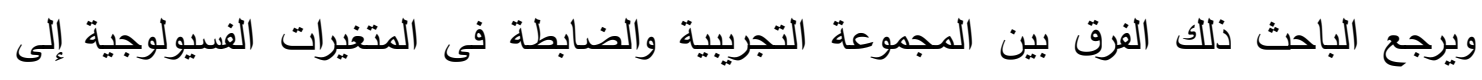

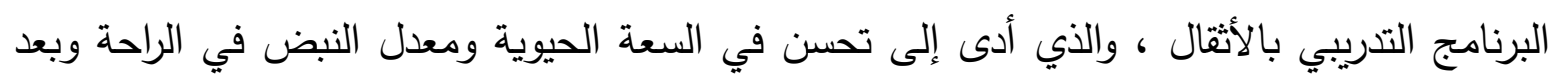

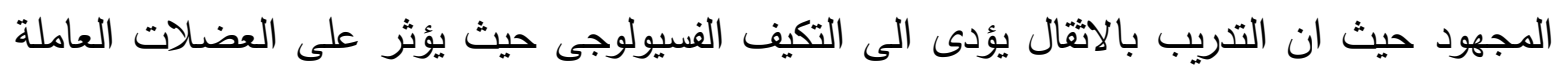

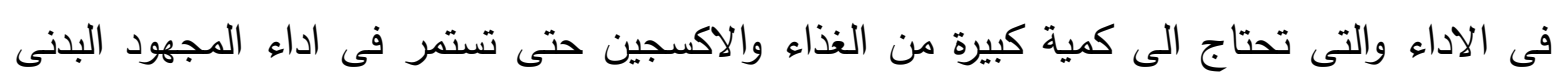

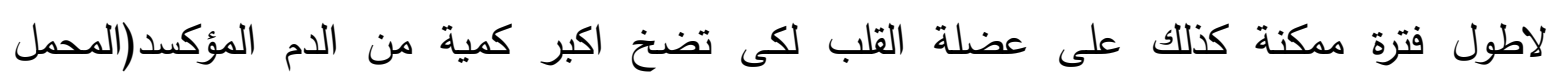

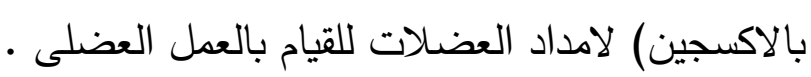

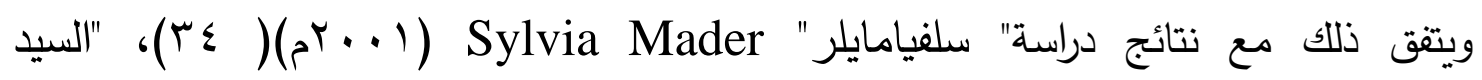

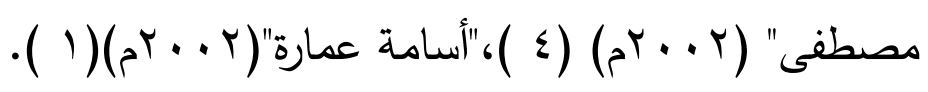

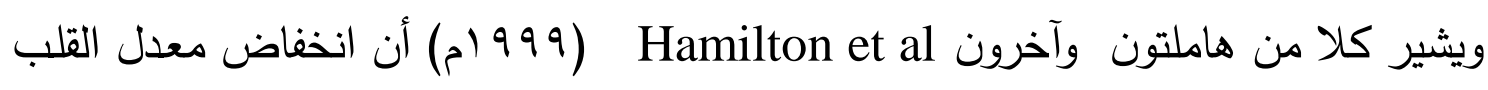

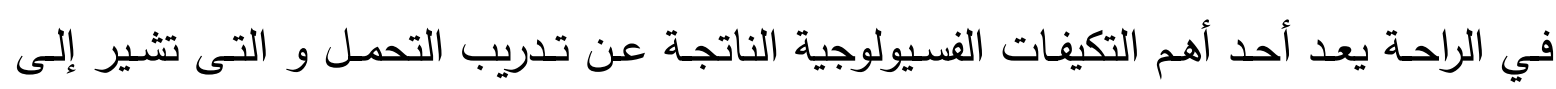

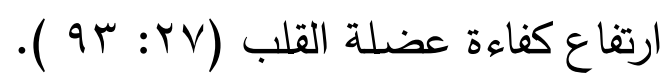

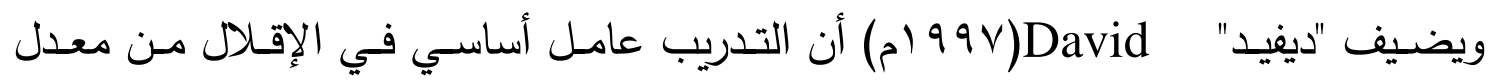

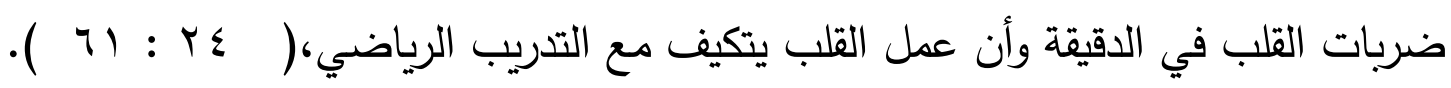

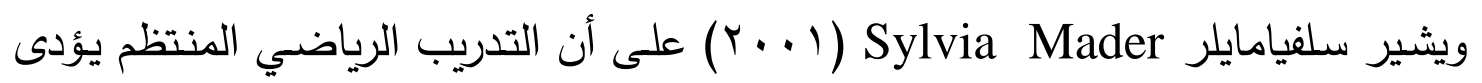

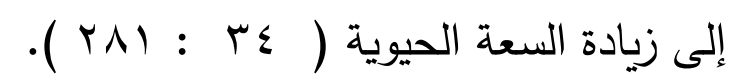
وبذلك يتحقى الفرض الخامس و الأي ينص على : لتى

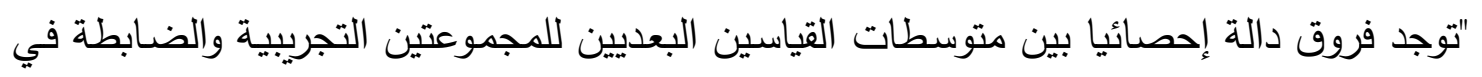

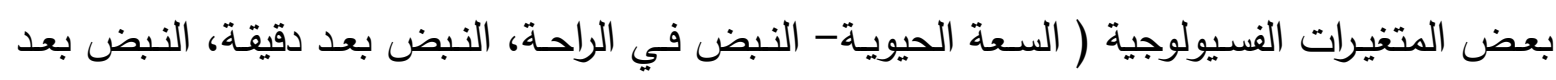
دقيقتين، النبض بعد ثلاث دقائق) لصالح المجموعة التجريبية". ؟-مناقثة الفرض السادس:-

يتضح من الجدول رقم ( • () وجود فروق دالة إحصـائية بين القياسين البعديين للمجموعـة

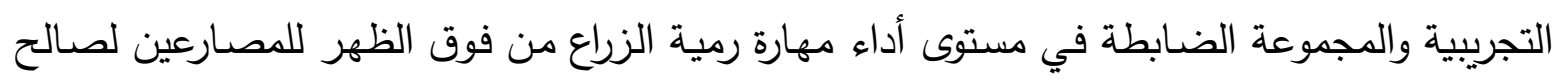
المجموعة التجريبية. 
ويرجع الباحث ذللك التحسن إلى برنامج الأتقال المقترح، وتتفق هذه النتائج مع ما أشارت إليه

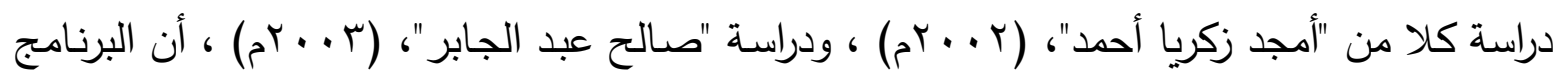

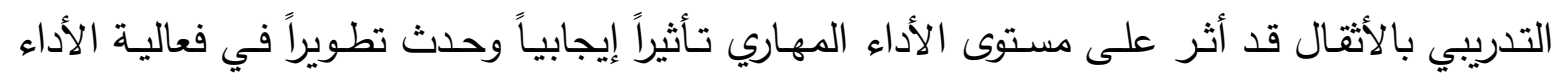

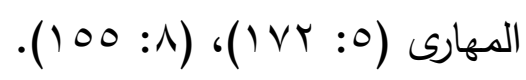

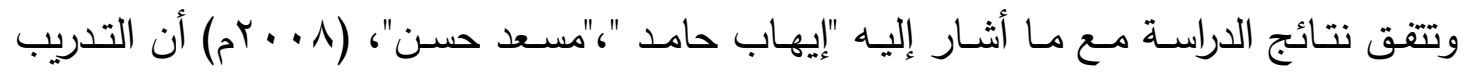

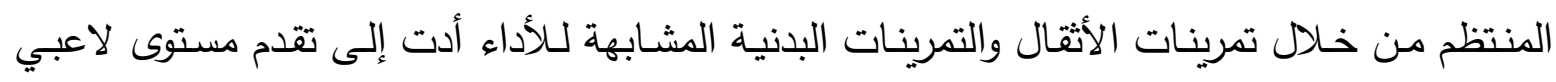

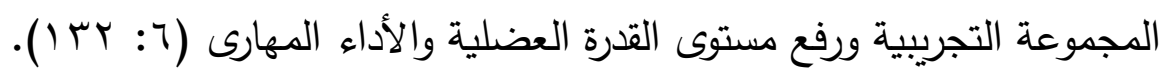

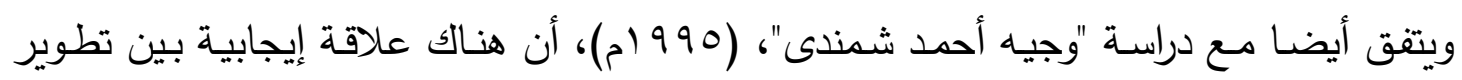

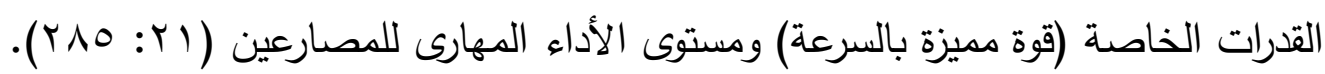

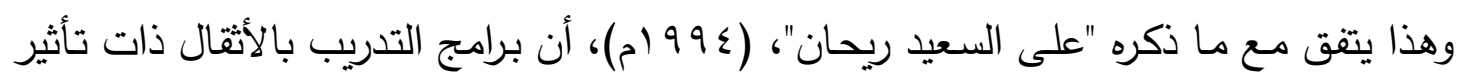

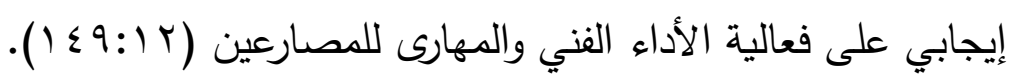

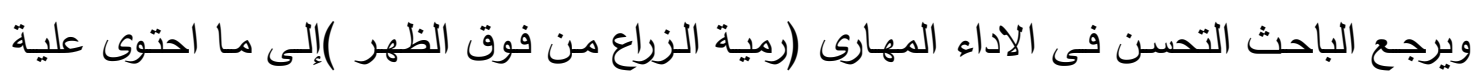

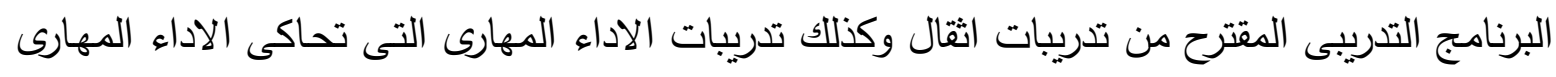

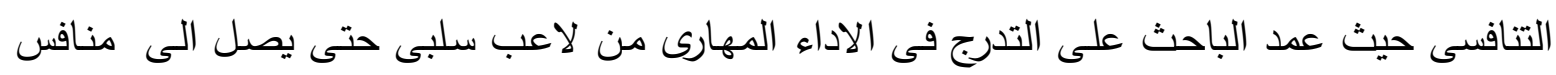

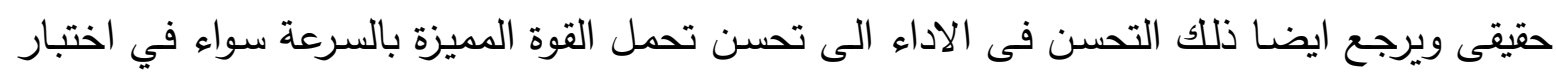

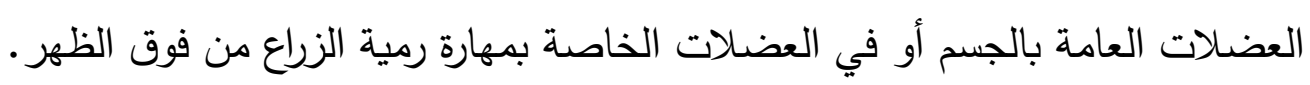

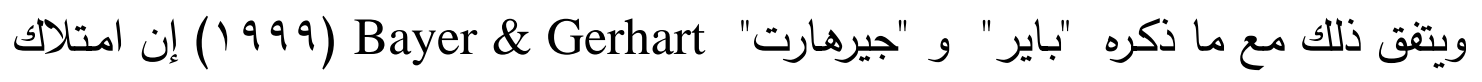
عنصر تحمل القوة المميزة بالسرعة والعمل على زيادة القدرات المرتبطة بالقوة المميزة بالسرعة

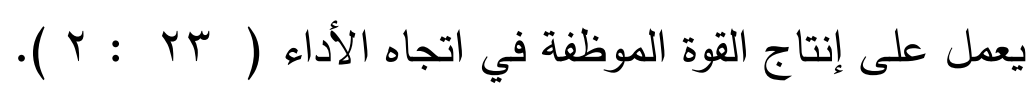

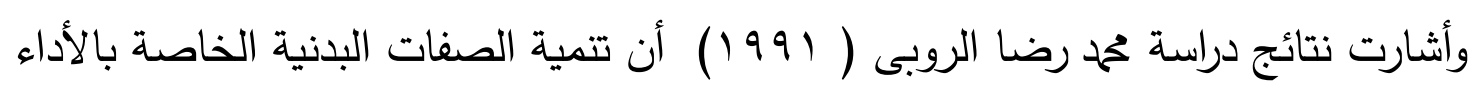

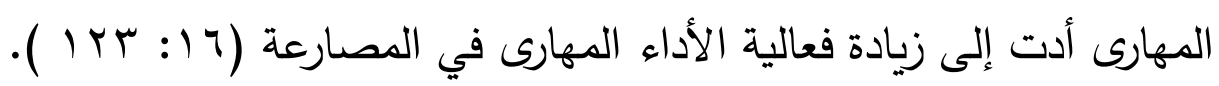

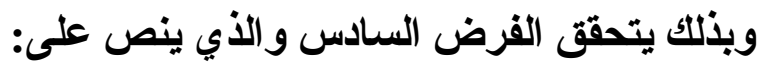

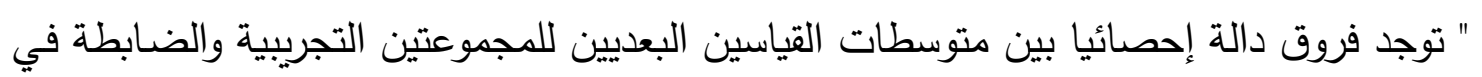
مستوى أداء مهارة رمية الزراع من فوق الظهر للمصارعين لصالح المجموعة التجريبية ". الاستخلاصات و التوصيات : أولا - الاستخلاصات : في حدود أهداف وفروض وإجراءات البحث وعرض ومناقثة النتائج توصل الباحث للاتي: - - البرنامج المقترح باستخدام تدريبات الاثقال أدى إلى تحسين المتغيرات البدنية والفسيولوجية والمهارية وصنية قيد البحث - - أظهرت نتائج الدراسـة تفوق المجموعـة التجريبية على المجموعـة الضـابطه في المتغيرات البدنية والفسيولوجية والمهارية قيد البحث لقن 
في حدود مجتمع البحث والعينة المختارة وفي ضوء أهداف البحث وفروضله وما توصل إلية من

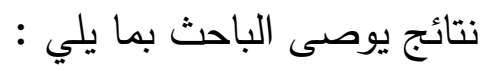
ا- استخدام تدريبات الاثقال المقترحة للارتقاء بمستوى عناصر اللياقة البدنية للمصارع (قوة مميزة

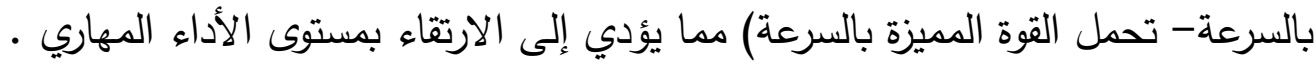

r- اهتمام المدربين بمهارة رميه الزراع من فوق الظهر مع مراعاة الطرق التدريبية المناسبة. r- إجراء المزيد من الدراسات حول عنصر تحمل القوة الميزة بالسرعة بشكل أكثر تععقا. ع - إجراء دراسات مماثلة على مراحل سنية مختلفةعلى عنصر تحمل القوة المميزة بالسرعة ومهارة

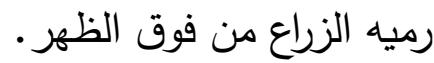

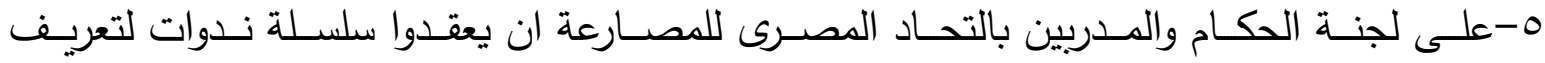
المتخصصين فى اللعبة والمهتمين بها عن تعديلات القانون لتحقيق اقصى استفادة من هذالتعديل من وجهة النظر التدريبية والتحكيمية واقتراح السبل للارتقاء باللعبة سواء محليا او دوليا. 


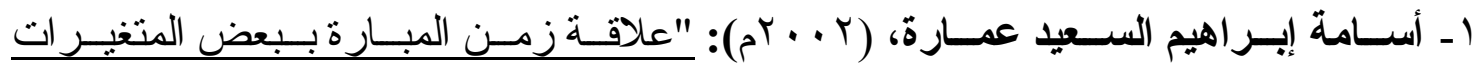

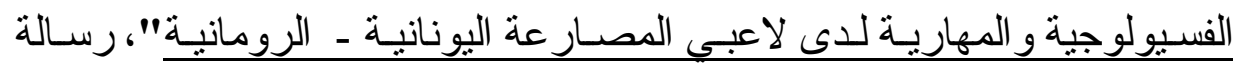
ماجستير، غير منشورة، كلية التربية الرياضية، جامعة أسيوط.

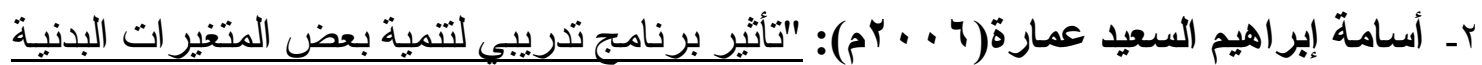
و الفسيولوجية لمهارة الخطفة الفنية الكبرى للمصار عين النانشئين"، رسالة دكتور اه ،غير منشورة،كلية التزبية الرياضية ،جامعة أسيوط .

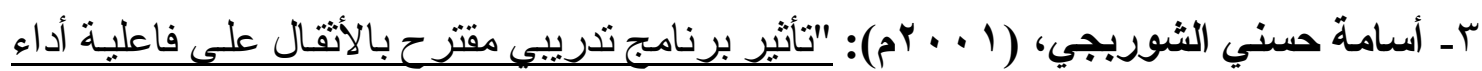
مهارة برمـة الصدر للمصـار عين الكبار "، رسالة ماجستير ، غير منشورة، كلية التربية الرياضية، جامعة طنطا.

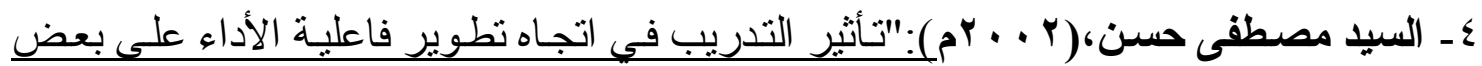

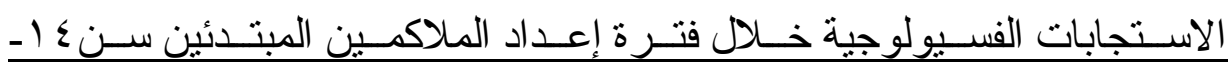
7 اسنة،رسـالة ماجستير ، غير منشـورة،كلية التزبيـة الرياضية للبنين، جامعـة الإسكندرية. هـ أمجد زكريا أحمد عبد العال، (r . بم): "أثز تطوير القوة المميزة بالسرعة على مستوى أداء مهارة حمل رجل المطافى وبعض المتغير ات الفسيولوجية للمصار عين"، رسالة ماجستير ، غير منشورة، كلية النربية الرياضية للبنين، جامعة الزقازيق.

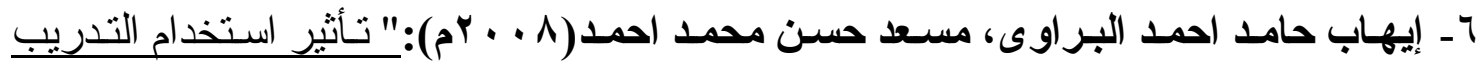

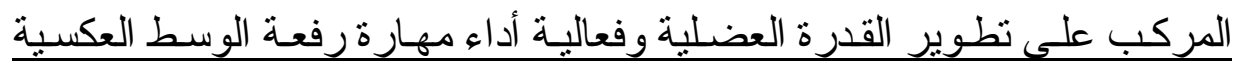

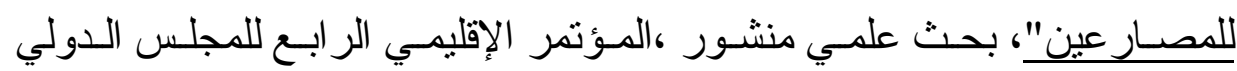

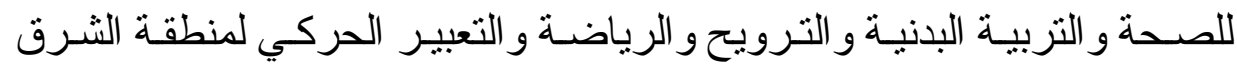
الأوسط،كلية التربية الرياضة للبنين بأبوقير ، جامعة الإسكندرية. 


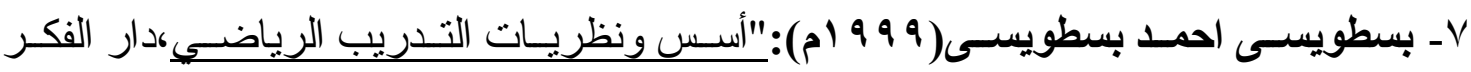
العربي،ط ا، القاهرة.

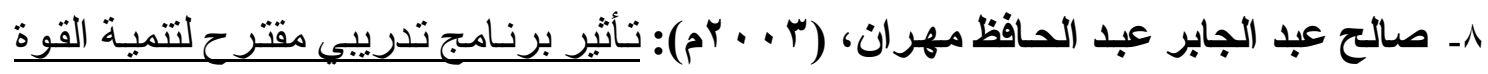

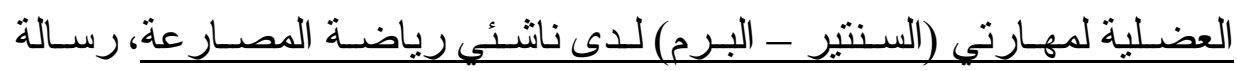
ماجستير غير منشورة، كلية التزبية الرياضية، جامعة أسيوط.

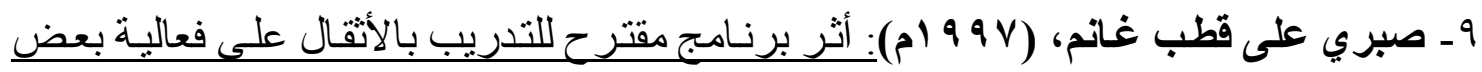

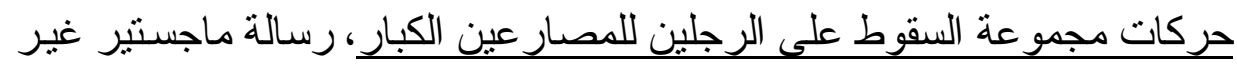
منشورة، كلية التزبية الرياضية للبنين، جامعة الإسكندرية.

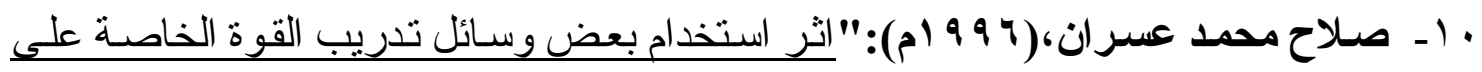

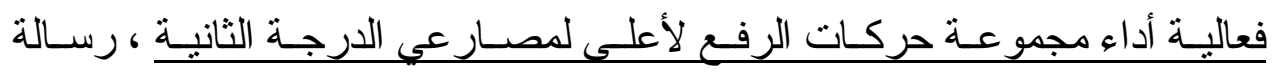
دكتور اه، غير منشورة،كلية التربية الرياضية للبنين،جامعة الإسكندرية.

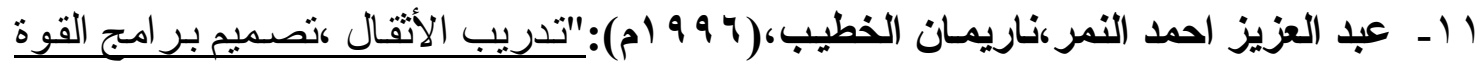
وتخطيط الموسم التثريبي،ط ا كمركز الكتاب للنشر ،القاهرة.

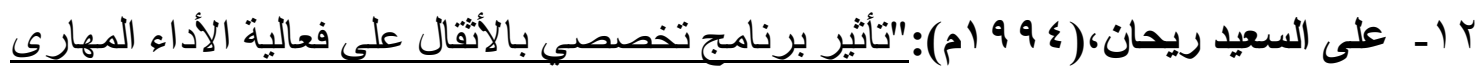

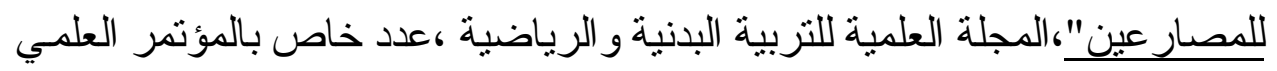

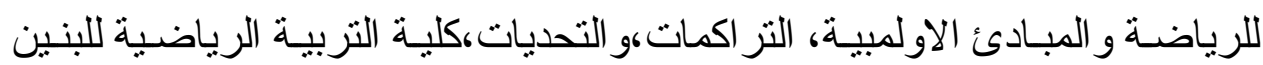

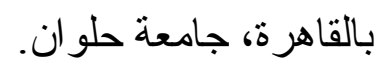
با ــ فاروق السيد عبد الوهاب :"الرياضة صحة ولياقة بدنية"،(999 (م)،دار الثروق، القاهرة.

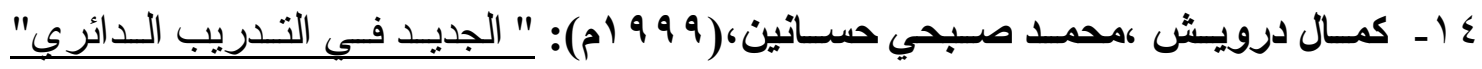
كطا كمركز الكتاب للنشر ،القاهرة.

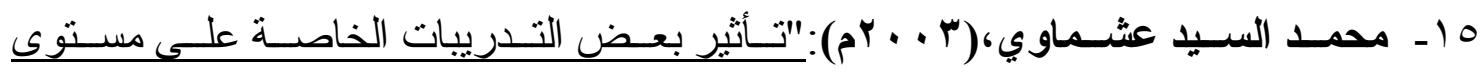

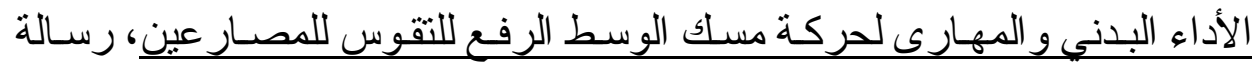
ماجستير ،كلية النزبية الرياضية للبنين ،جامعة الزقازيق.

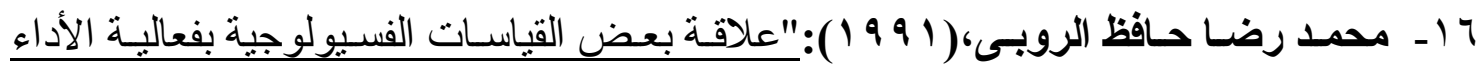

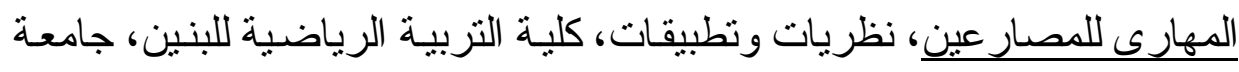

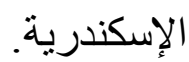

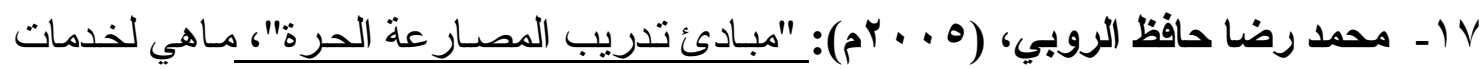

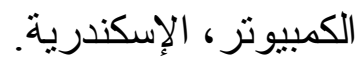




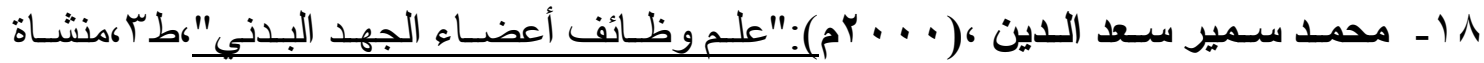
المعارف، الإسكندرية.

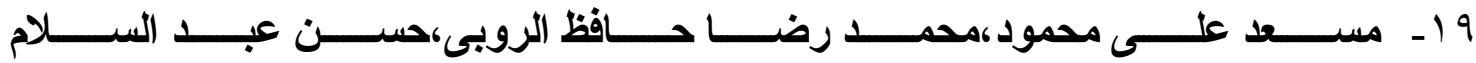

محفوظ،(9 99 (9)م)؛:"الأسـس النظريـة و التطبيقيـة للمصـار عة الرومانبـة و الحـرة، دار الكتب

$$
\text { القومية، المنصورة. }
$$

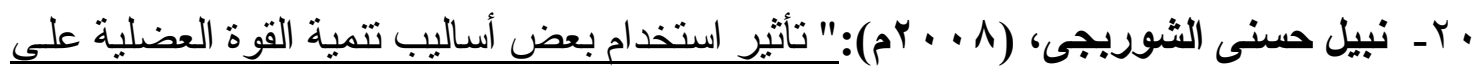

الفعالية أداء مهارة رفعـة الوسط العكسية للمصسار عين"، المؤتمر الإقليمي الر ابع

للمجلس الدولي للصـحة والتربيـة البدنية و الترويح و الرياضية و التعبير الحركي

لمنطقة الثـرق الأوسـ، الجزء الثالث، كليـة التربيـة الرياضية للبنين بـأبو قير ،

$$
\text { جامعة الإسكندرية. }
$$

ا Y - وجيـه أحمـد شـمندى، (990 (م): تـأثنير برنـامج تدريبي لتطـوير بعض القدر ات الحركيـة

الخاصة على فاعلية الأداء المهارى و الخططى للمصـار عين، المجلة العلميـة للتربيـة

البدنيـة و الرياضية، العدد الثالث و العشـرين، كليـة التربيـة الرياضية للبنين، جامعـة

حلو ان، القاهرة.

ثانيا المر اجع باللغة الأجنبية:

22-Alan Boras(2003) : Training Four Endurance Sports,Palmer

Nordic Ski Team.

23-Bayer,Gerhart(1999):Untersuchungenzur Bewegungsgeschwidigkeit

als Belastungskennziffer im Krafttraining

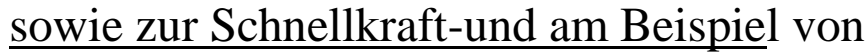

Rudersportlern.

24-David,A.,(1997): Wellnes Concepts and application Library of congress cataloging in publication data ,New York.

25-Ebben,W.p.,watts,p.B.,jensen,R.L.and Blackard,D.o,(2000):

$\underline{\text { EMG and kinetic analysis of complex training }}$

exercise variables.journal of strength and

conditionong Research 14(4),451-456.

26-Faiona Hayes, A(1998): Cras Training A andC Blak publishers

Ltd,London . 
27-Hamilton,K.L.,(1999): Physiological adaptation to exercise for sports medicine ,edited by maughan R.j., butter worth heineman co., oxford,U.K.

28- Howlly,T.H.\&franks,D.B.,(1997):Health fitness hand book3,rd.,liber of congress cataloging in publication date.

29-kritpet,t.,\&Meesinm C.,(1995):Effects of weight training and polymeric on muscular power, starting time and distaance of swimmers 18sea games scientific congres, theories to practice ,change,mai,thailand

30-Martin,W.R.\&Margherita.A.J.,(1999):Wrestling ,Phys.Med., Rehabil.N.Am.,Vol.10,No.1Feb

31-Mayhew,J.L., Prinster ,J.L\&Ware,J.S.,(1995): Muscular endurance repetitions to predict press strength in men of different training levels, the journal of sport medicine and physical,Vol.35,No.2,june.

32- Novikov, A. (1991): Lallenamenta della Forza nella formazione del lottatore strength training for wrestlers, Athlon, Roma.

33-Resser,J.C.8Bahr,r.,(2003): Hand Book of sports medicine and science co .,Oxford,U.K.

34-Sylvia S.Maeler.,(2001):Understanding human anatomy and physiology,library of congress cataloging in publishing data.New York.

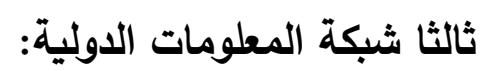
35http://highschoolsports.nj.com/news/article/5650758906257151368/wrestli /ng-fila-junior-national-preview 


\section{ملحقات البحث}

استمارة تفريغ البيانات للاعبين.

ملحق رقم (1)

قائمة بأسماء السادة الخبر اء، و الحكام المقيمين للأداء المهارى.

ملحق رقم (ץ)

الاختبار ات المستخدمة في البحث.

ملحق رقم (")

نمازج من البرنامج المقترح ـ .

ملحق رقم (๕) 


\section{ملحق (1)}

\section{استمارة تفريخ البيانات للاعبين

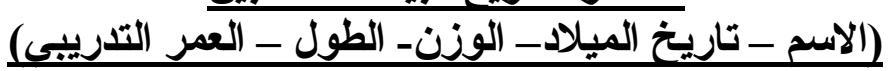

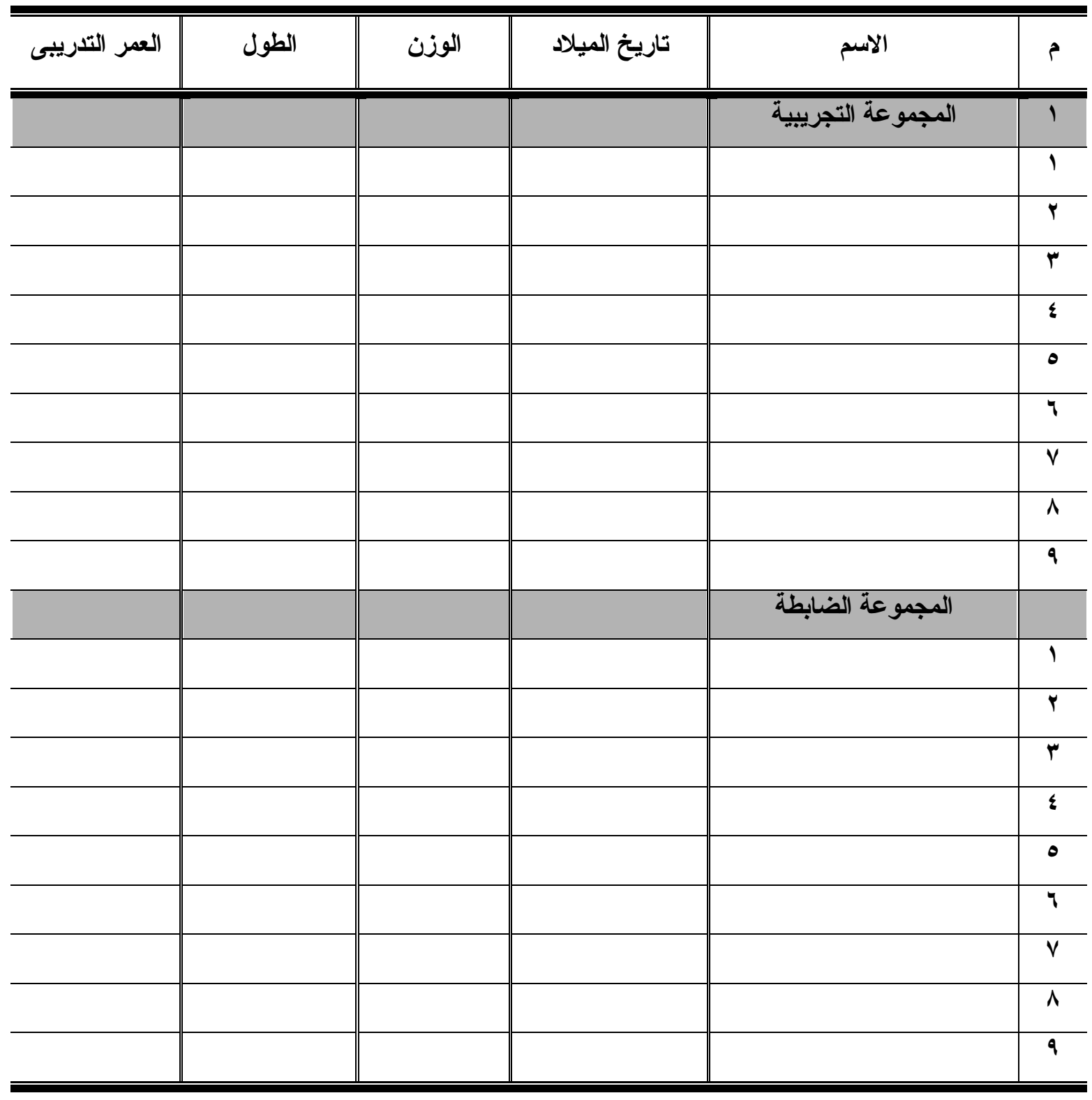

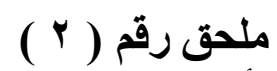

قائمة بأسماء السادة الخبر امث ( 


\begin{tabular}{|c|c|}
\hline الصـفة & الاســـــم \\
\hline 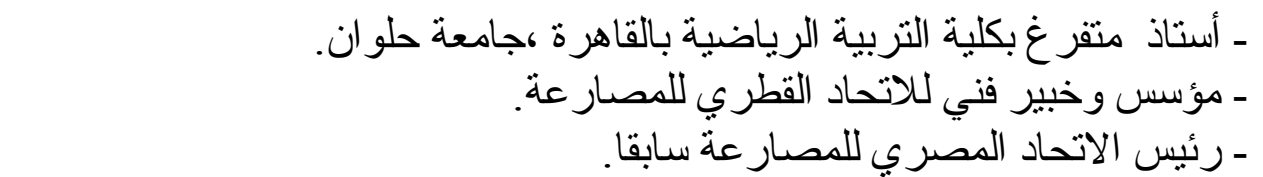 & أ.د// احمد عحم عبدالمعز السنتريسى \\
\hline ـ أستاذ مساعد تخدصة الزقازيق. مصدسار عة بقسم الترريب الرياضي، كلية التربية الرياضية & أ.م.د/ أمجد زكريا احمد عبد العال \\
\hline - عض عضاذ تدريب المصسارعة بقسم التدريب الرياضي بكلية التربية الرياضية،جامعة & أ.د/ إيهاب فوزي البديوى \\
\hline 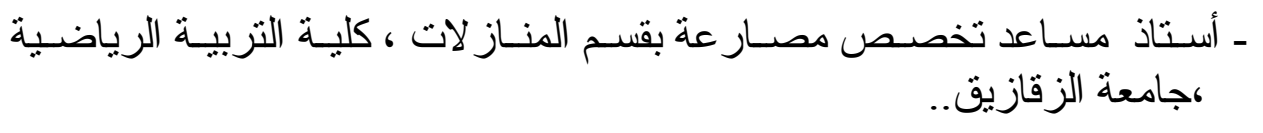 & أ.م.د / إيهاب كحمد الصادق \\
\hline - ـ رئيس لجنة مساعد المكام بمنطقة أسية التزبية الرياضية - جامعة أسيوط دولية & أ.م.د / صالح عبد الجابر مهران \\
\hline أستاذ تدريب المصارعة بكلية التربية الرياضية للبنين بابو قير ،جامعة الإسكندرية & أ.د/صلاح عحم عسران \\
\hline 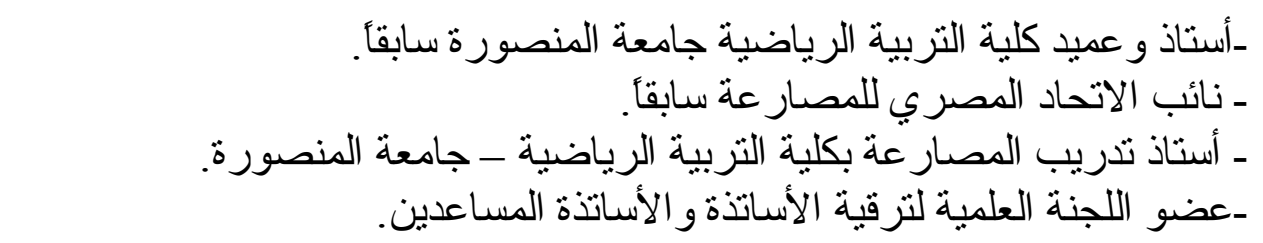 & أ.د/مسعد على محمود \\
\hline
\end{tabular}

قائمة بأسماء الحكام

\begin{tabular}{|c|c|}
\hline الصــفة & الاســـــــم \\
\hline - رئيس لجنة الحكام بمنطقة أسيوط. للمصار عة سابقا. & 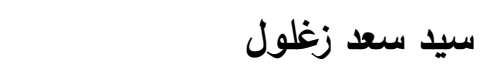 \\
\hline 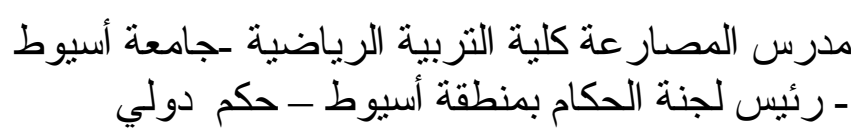 & أ.م.د / صالح عبد الجابر مهران \\
\hline ـ حكم درجة أولى بمنطقة أسيوط. للمصار عة. & مر جلال عبد القادر \\
\hline
\end{tabular}




$$
\text { الاختبارات المستخدمة فِّي البحث }
$$

\section{1- - اختبار القوة المميزة بالسرعة}

$$
\text { أولا :الاختبار ات البدنية }
$$

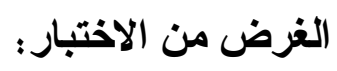

قياس القوة المميزة بالسر عة في مهارة( رمية الزر اع من فوق الظهر)،(تصميم الباحث)..

$$
\text { الأدوات: - بساط مصار عة. }
$$

- ماعة إيقاف Stop Watch لقياس الزمن.

$$
\text { طريقة الأداء: }
$$

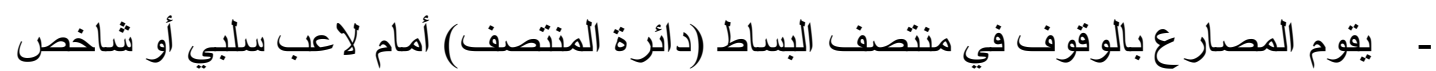

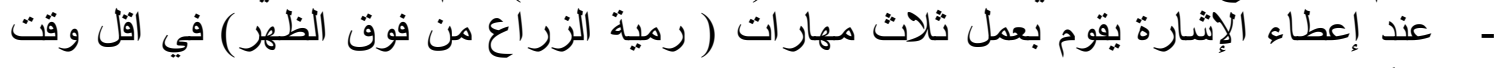

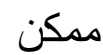
تعليمات الاختبار :

- - يقوم المصار ع بعمل الإحماء المناسب قبل القياس لمدة (0) دقائق.

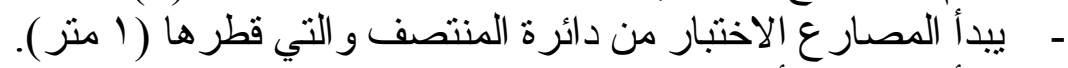

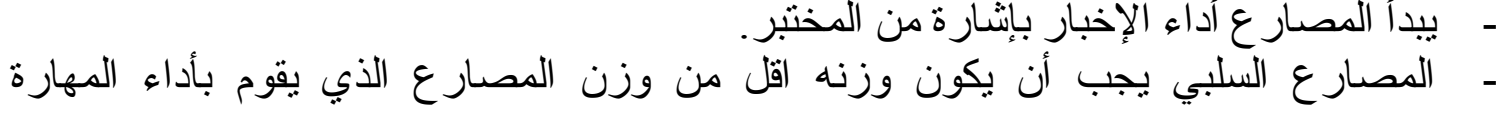

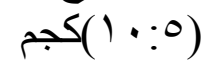

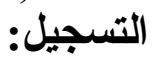
يتم تسجيل الزمن الذي يستغرقه المصار ع في أداء الثلاث مهار ات بالثانية
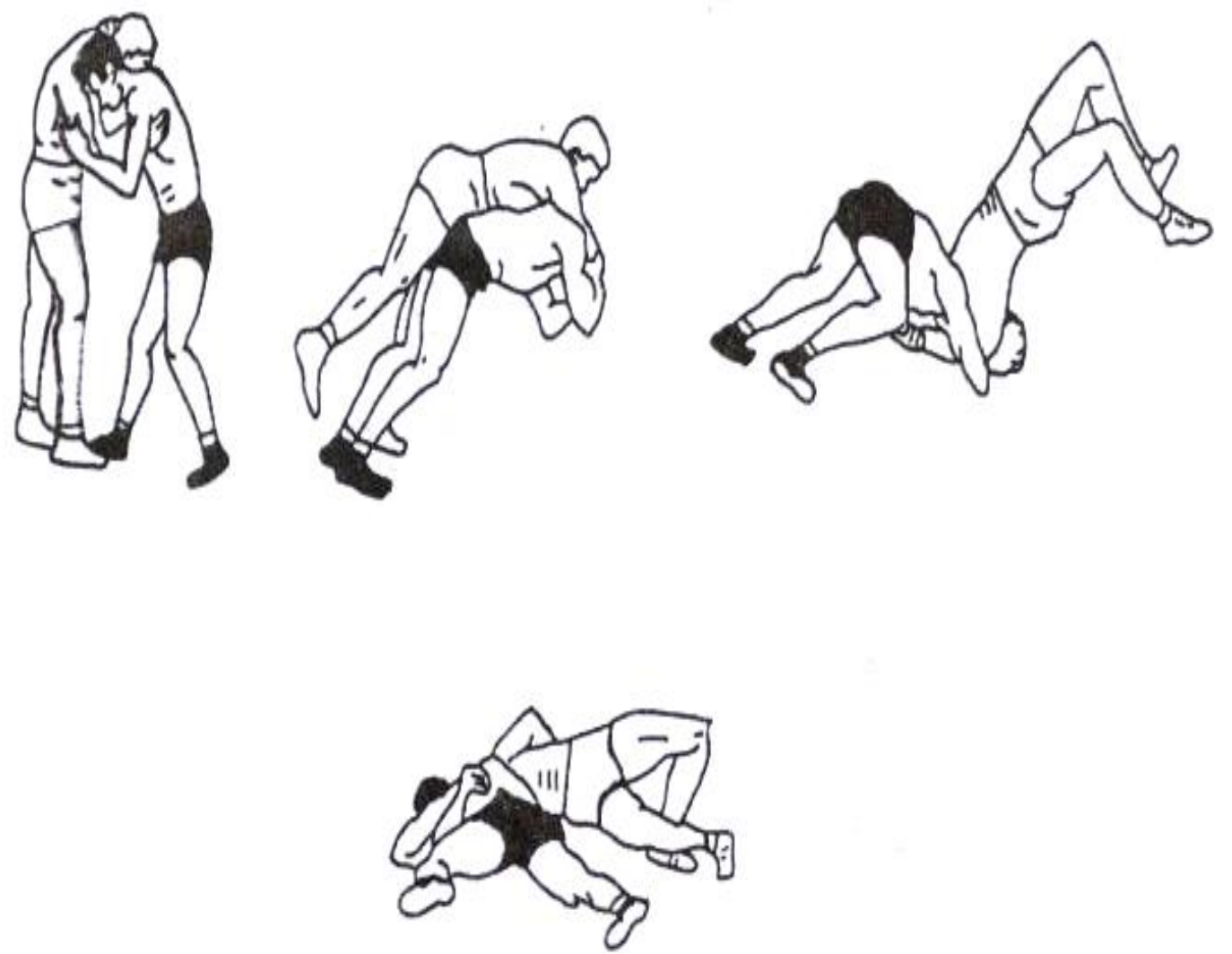
r- اختبار تحمل القوة المميزة بالسرعة(الرفعة المميتة)

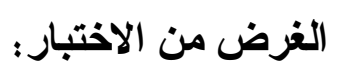

قياس تحمل القوة المميزة بالسر عة لعضلات الجسم .

$$
\text { - }
$$

-

$$
\text { - - مريقة الأداء: - مقوم المصار ع بالوقوف فتحا أمام البار الحديدي. }
$$

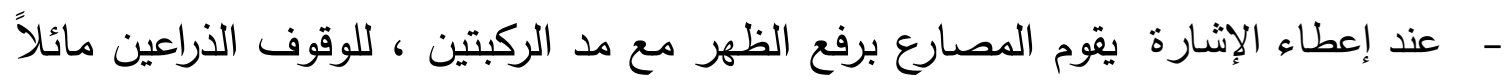

أماماً أسفل.

$$
\begin{aligned}
& \text { - تعليمات الاختبار: يقوم المصار ع بعمل الإحماء المناسب قبل القياس لمدة (0) دقائق. }
\end{aligned}
$$

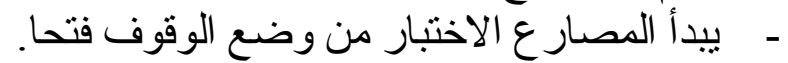

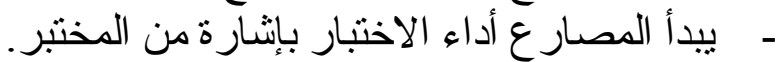

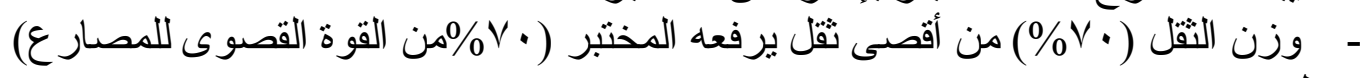

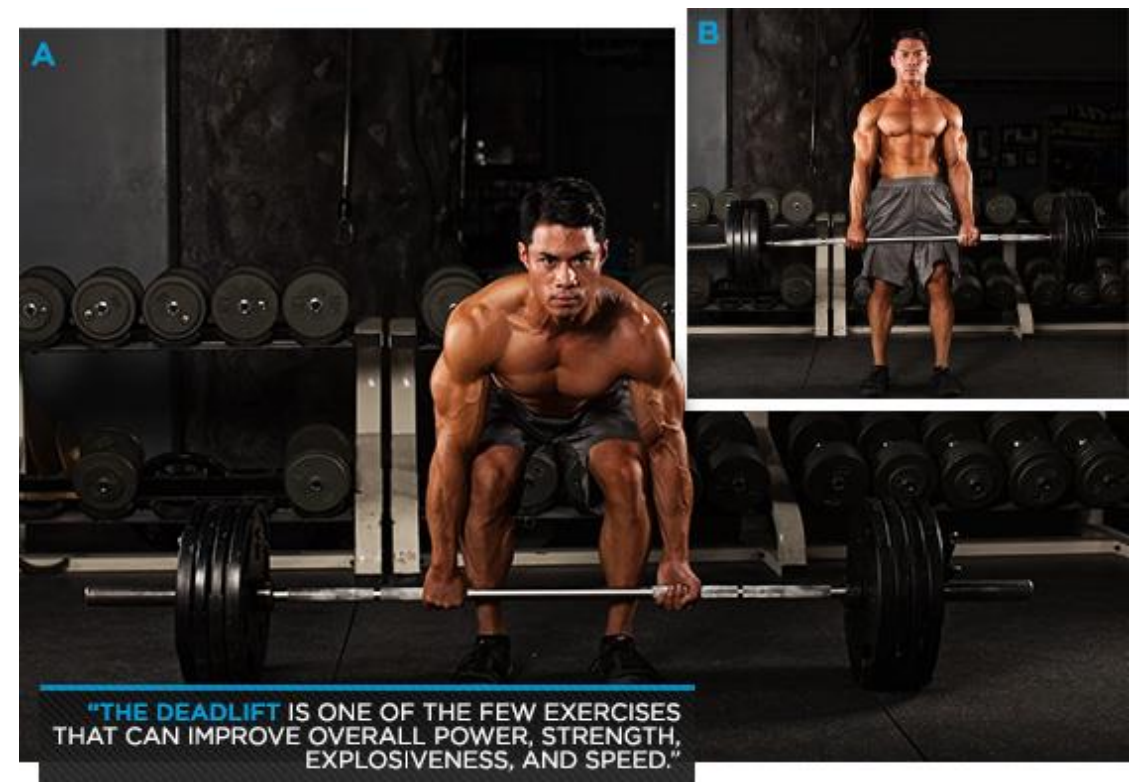

(7) 
rـ اختبار تحمل القوة المميزة بالسرعة للعضلات العاملة في مهارة رمية الزراع من فوق الظهز ،(تصميم الباحث).

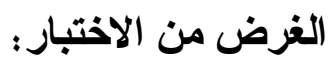
قياس تحمل القوة المميزة بالسر عة للعضلات العاملة في مهارة رمية الزر اع من فوق الظهر

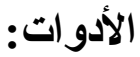

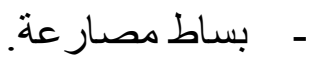
- ساعة إيقاف Stop Watch لقياس الزمن

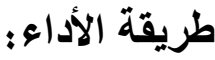

- - يقوم المصار ع بالوقوف في منتصف البساط (دائرة المنتصف) أمام لاعب سلبي أو شاخص - - - عند إعطاء الإشارة يقوم بعمل مهارة ( رمية الزر اعن من فوق الظهر ) .

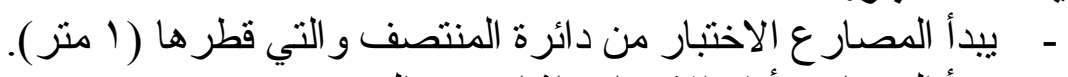

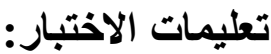

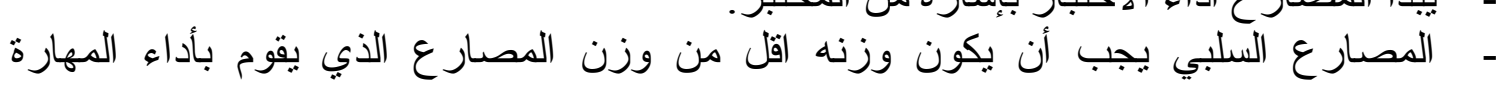

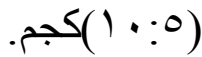

- - يسمح للمختبر باستكمال الأداء من أي مكان فوق البساط دون الرجوع لنقطة البداية

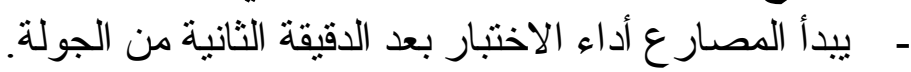

يتم تنجيل اكبر عدد ممكن من تكر ار ات مهارة ( رمية الزر اع من فوق الظهر ) خلال • آثانية
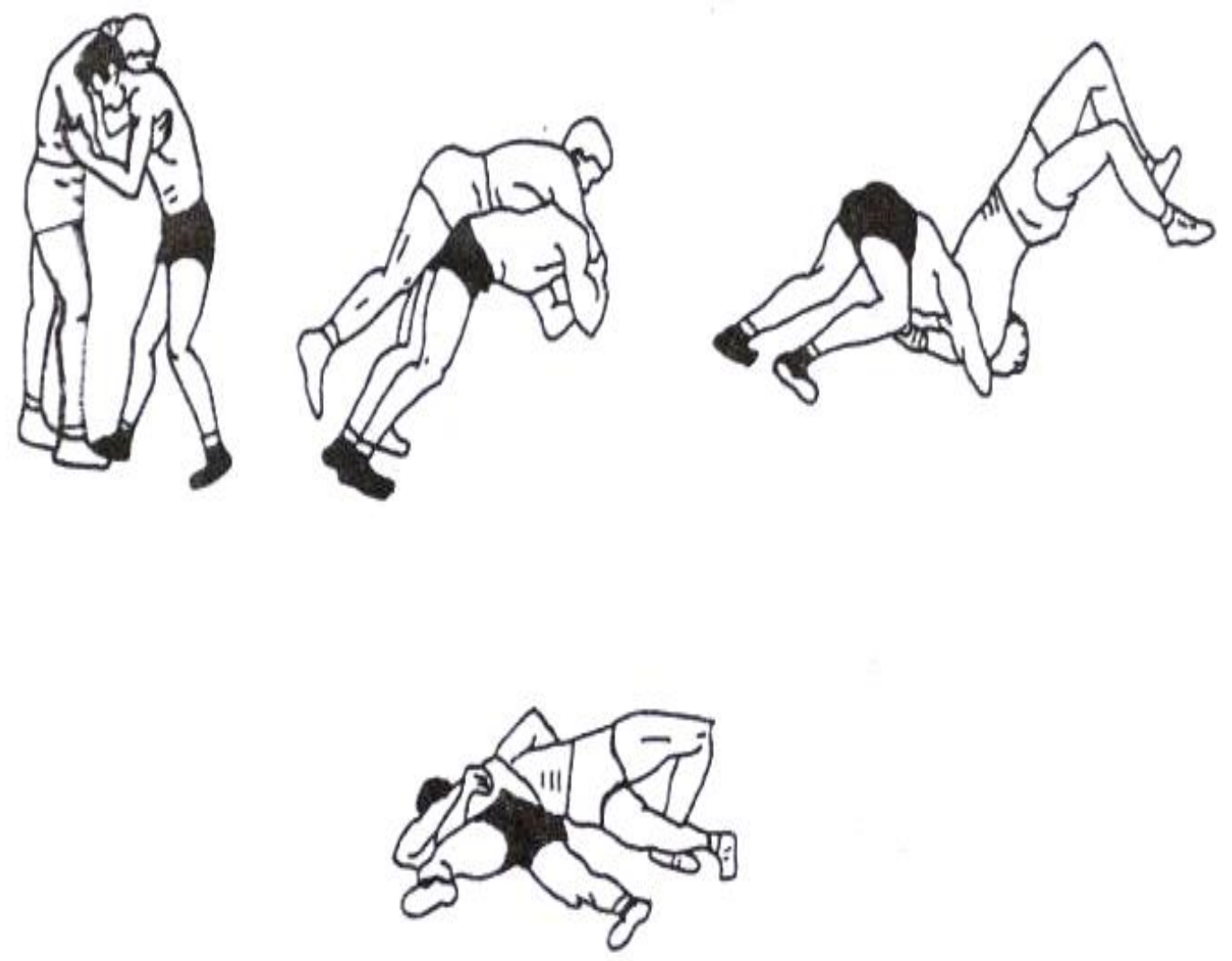
ثانيا :الاختبار ات الفسيولوجية

1- قياس النبض:

تم قياس معدل ضربات القلب في كل من الراحة وبعد أداء المجهود البدني من منطقة الشريان الكعبرى و لمدة ( • ( ثوان X Y ) ) ، وقد تم القياس في وقت الراحة لمرة واحدة ، ثم بعد أداء

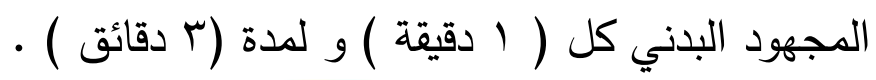

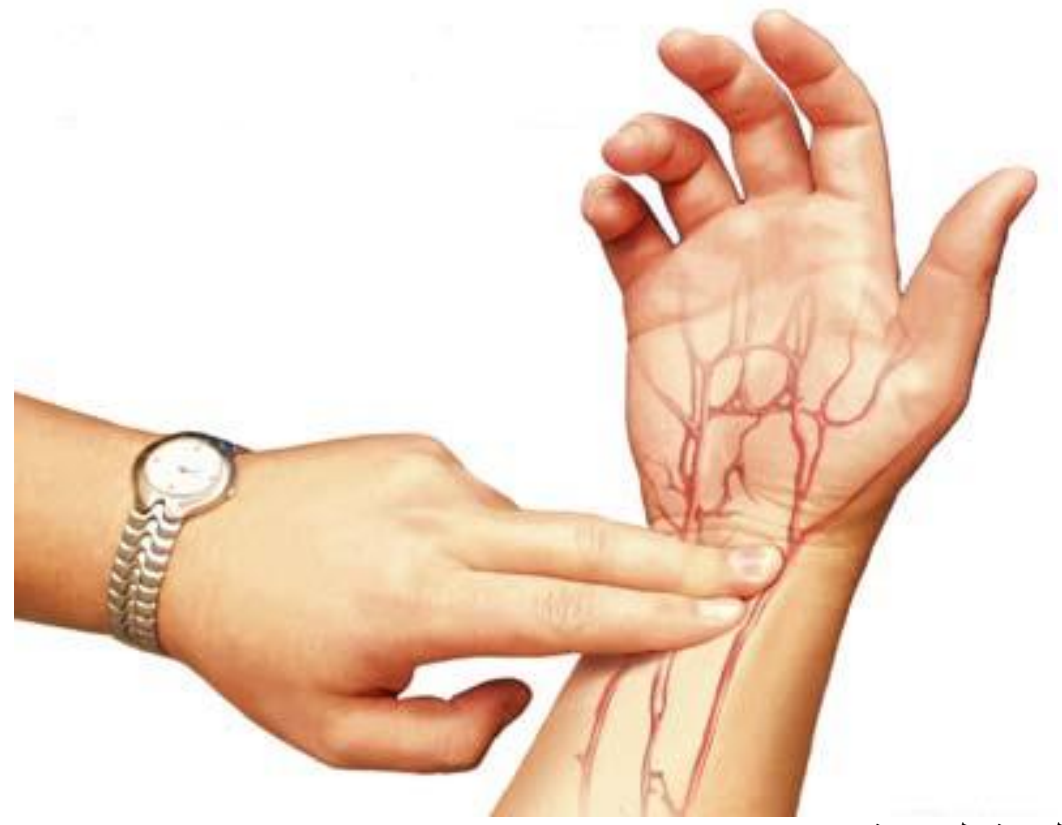

r- اختبار السعة الحيوية:

تم قياس السعة الحيوية (VC) باستخدام جهاز الأسبيروميتر الجاف وذللك بأن يقوم اللاعب بأخذ أقصى شهيق ثم إخراجه بأقصى زفير في مبستهم الجهاز الذي يحدد قراءة القياس

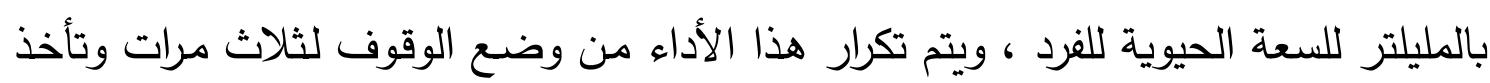

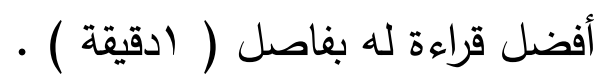

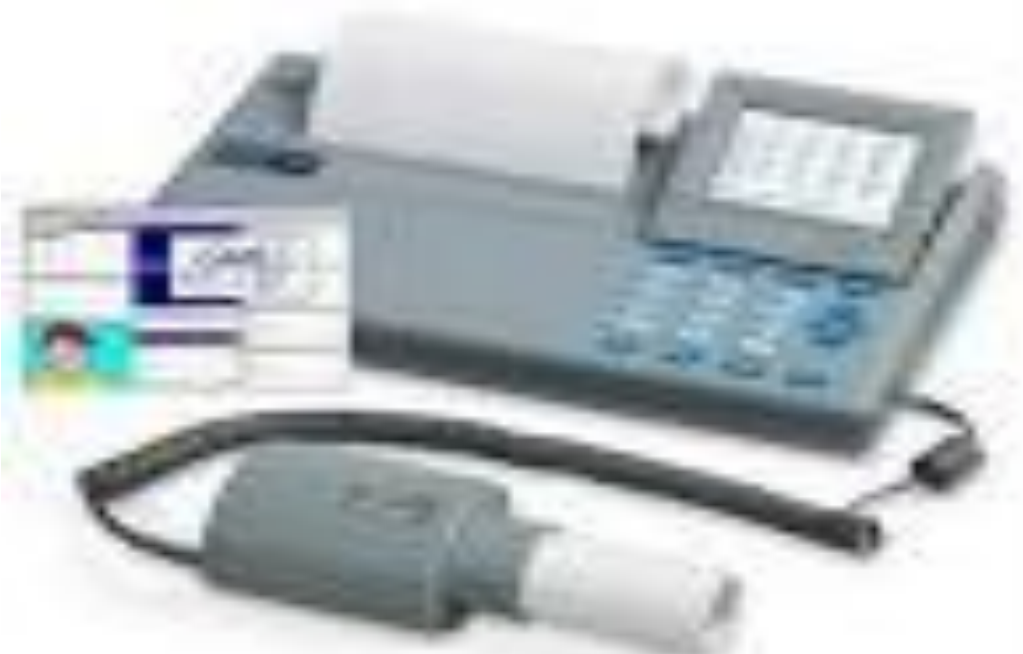

(11) 
1 ـ فعالية أداء مهارة رمية الزراع من فوق الظهر (حكام مقيمين)،(تصميم الباحث).

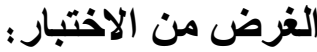

قياس فعالية أداء مهارة رمية الزر اعن من فوق الظهر خلال (. آث)

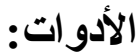

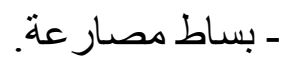$$
\text { - 2 - 2 - لاعب سلبي. }
$$

ـ - ماعتمارة لتقبيم فعالية الأداء.

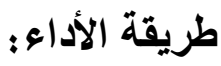

- - يقوم المصار ع بالوقوف في منتصف البساط (دائرة المنتصف) أمام لاعب سلبي أو شاخص - - عند إعطاء الإشارة يقوم بعمل مهارة ( رمية الزر العاع من فوق الظهر ) .

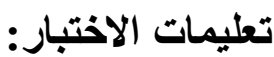

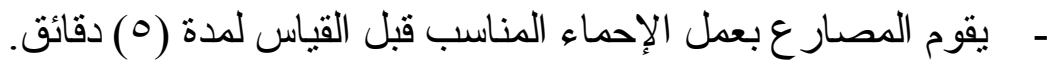

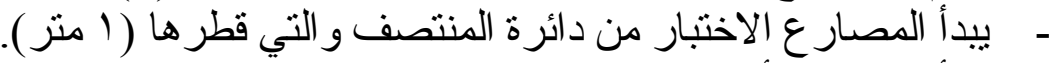

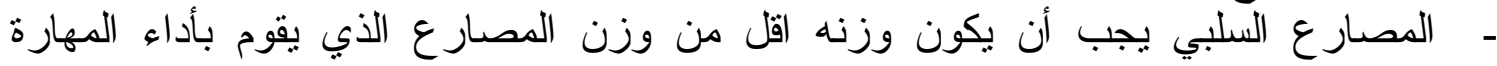

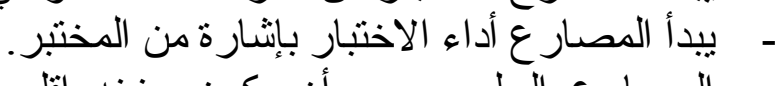

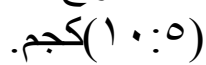

- - يسمح للمختبر باستكمال الأداء من أي مكان فوق البساط دون الرجوع لنقطة البداية - - غير مسمو ح باختصار أو تعديل الأداء. - أن ينعرض ظهر المصار ع السلبي للبساط أثناء الأداء.

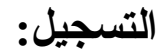

يتم اداء اكبر عدد ممكن من مهارة رمية الزراع من فوق الظهر خلال (· آث) ثم يتم تسجيل

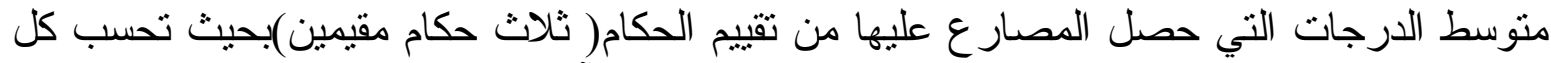
مهارة صحيحة بـ( • ( نقطة) ويتم تطبيقها على معادلة الفاعلية الآتية:

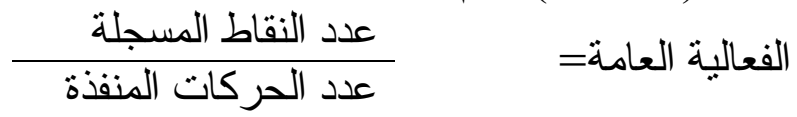

(Y0T:IV)

استمارة تقييم فاعلية أداء مهارة رمية الزراع من فوق الظهر على عينة البحث

\begin{tabular}{|c|c|c|c|c|c|c|c|c|c|c|}
\hline 9 & $\wedge$ & $v$ & 7 & 0 & $\xi$ & $r$ & r & 1 & التقييم & \\
\hline & & & & & & & & & $r$ & 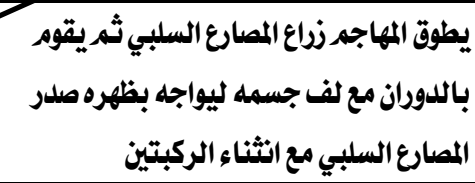 \\
\hline & & & & & & & & & $\xi$ & 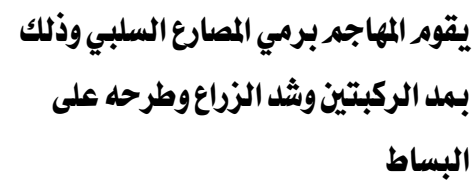 \\
\hline & & & & & & & & & $r$ & تعريض كتفي المصارع للبساط \\
\hline & & & & & & & & & درجات & المجموع \\
\hline
\end{tabular}




\begin{tabular}{|c|c|c|c|c|c|}
\hline . ا دقيقة & مكدق بقةــــة & زمن الأداء الكلي & V ا دقيقة & | ادقيقة & V دقيقة V V \\
\hline
\end{tabular}

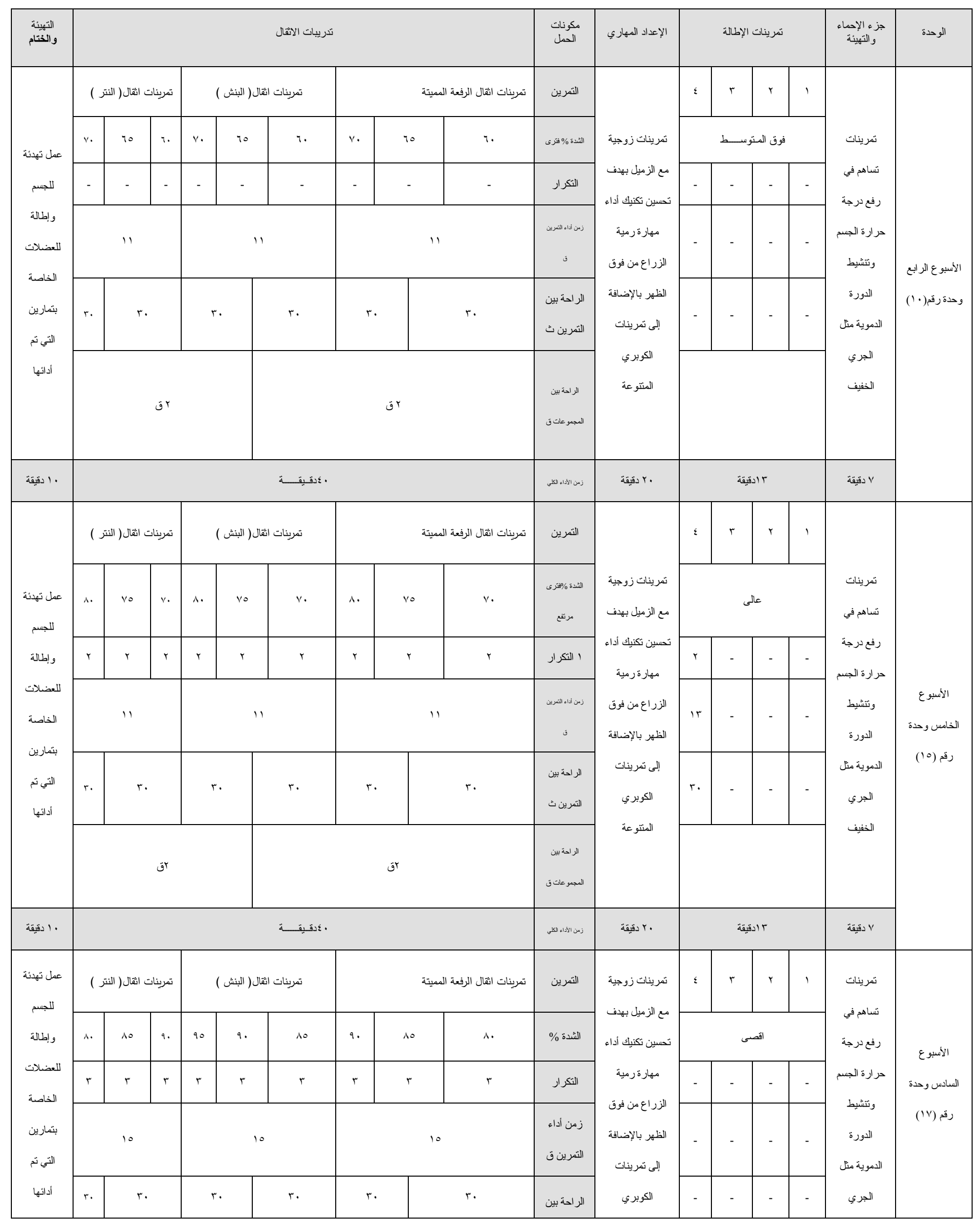




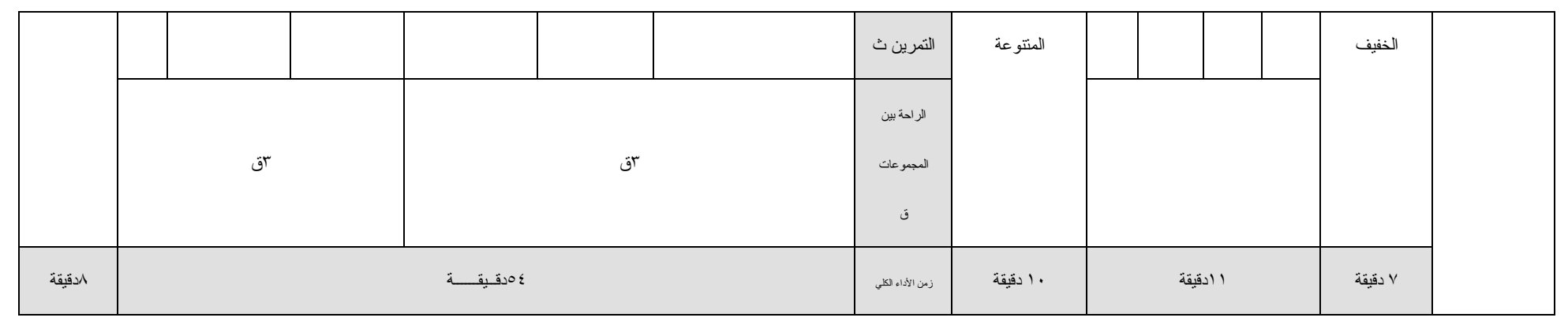

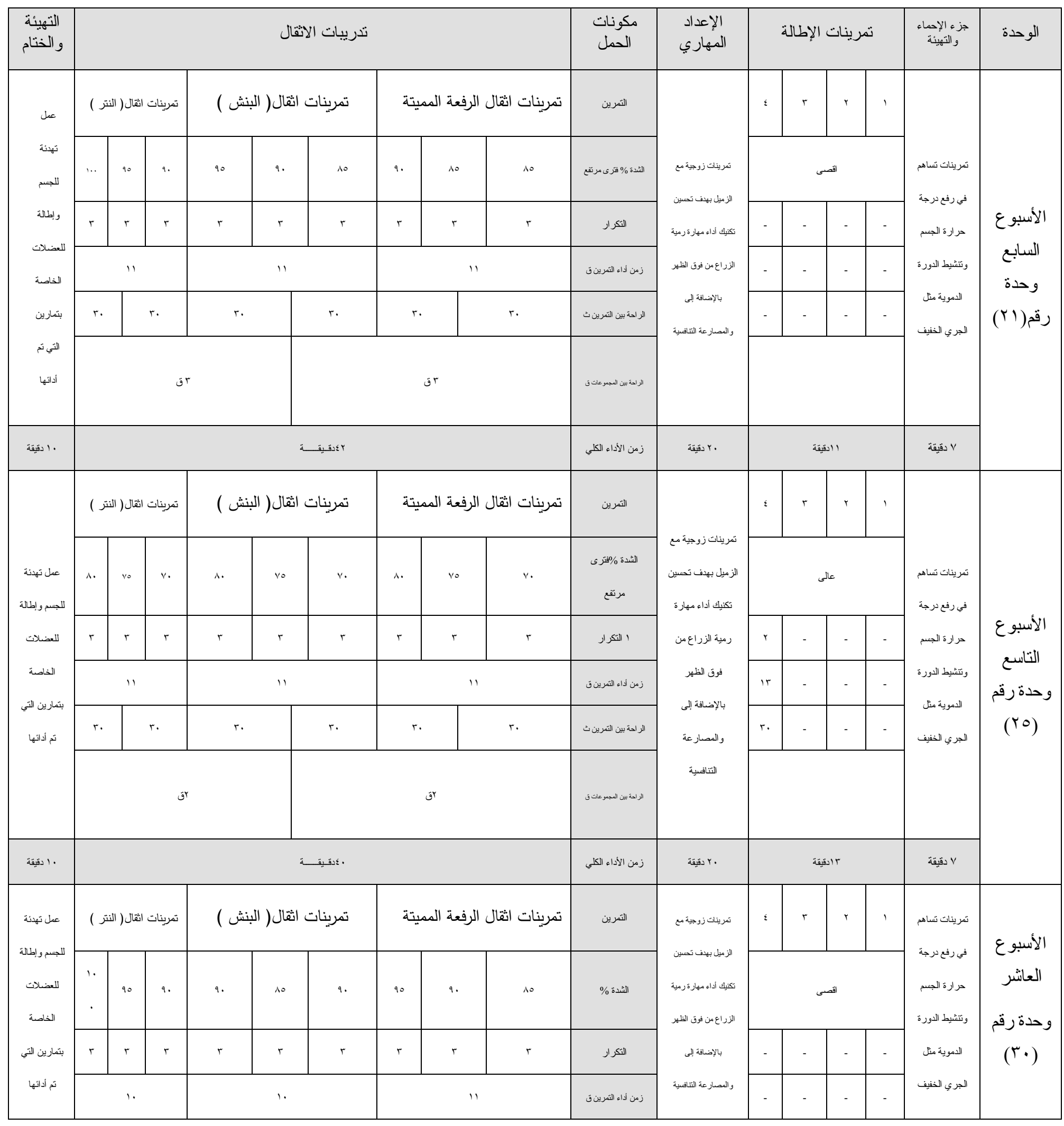




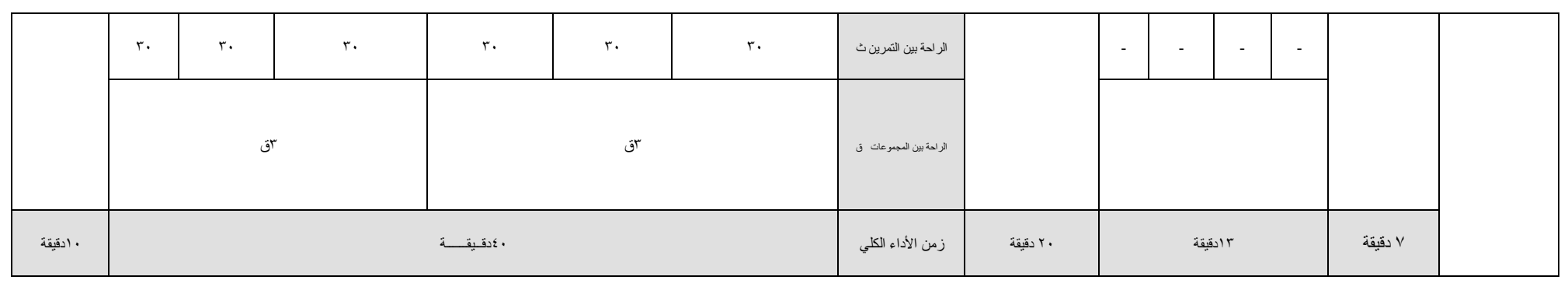

4 